\title{
Innate Lymphoid Cells in Intestinal Homeostasis and Inflammatory Bowel Disease
}

\author{
Angela Saez ${ }^{1,2,+}$, Raquel Gomez-Bris ${ }^{1,3,+}{ }^{\mathbb{D}}$, Beatriz Herrero-Fernandez ${ }^{1,3,+}$, Claudia Mingorance ${ }^{1}$, \\ Cristina Rius $4,5,6$ and Jose M. Gonzalez-Granado $1,3,5,6, * \mathbb{D}$
}

1 LamImSys Lab, Instituto de Investigación Hospital 12 de Octubre (imas12), 28041 Madrid, Spain; angela.saez@ufv.es (A.S.); rgomez.imas12@correo.h12o.es (R.G.-B.); beatriz.herrero@uam.es (B.H.-F.); claumingo.imas12@h12o.es (C.M.)

2 Facultad de Ciencias Experimentales, Universidad Francisco de Vitoria (UFV), 28223 Madrid, Spain

3 Departamento de Fisiología, Facultad de Medicina, Universidad Autónoma de Madrid (UAM), 28029 Madrid, Spain

4 Faculty of Biomedical and Health Sciences, Universidad Europea de Madrid (UEM), Villaviciosa de Odón 28670 Madrid, Spain; cristina.rius@universidadeuropea.es

5 Centro Nacional de Investigaciones Cardiovasculares (CNIC), 28029 Madrid, Spain

6 CIBER de Enfermedades Cardiovasculares, 28029 Madrid, Spain

* Correspondence: jmgonzalez.imas12@h12o.es; Tel.: +34-913908766

+ These authors contributed equally to this work.

Citation: Saez, A.; Gomez-Bris, R.; Herrero-Fernandez, B.; Mingorance, C.; Rius, C.; Gonzalez-Granado, J.M. Innate Lymphoid Cells in Intestinal Homeostasis and Inflammatory Bowel Disease. Int. J. Mol. Sci. 2021, 22, 7618. https://doi.org/10.3390/ ijms22147618

Academic Editor: José Luis Subiza

Received: 22 June 2021

Accepted: 14 July 2021

Published: 16 July 2021

Publisher's Note: MDPI stays neutral with regard to jurisdictional claims in published maps and institutional affiliations.

Copyright: (c) 2021 by the authors. Licensee MDPI, Basel, Switzerland. This article is an open access article distributed under the terms and conditions of the Creative Commons Attribution (CC BY) license (https:// creativecommons.org/licenses/by/ $4.0 /)$.
Abstract: Inflammatory bowel disease (IBD) is a heterogeneous state of chronic intestinal inflammation of unknown cause encompassing Crohn's disease (CD) and ulcerative colitis (UC). IBD has been linked to genetic and environmental factors, microbiota dysbiosis, exacerbated innate and adaptive immunity and epithelial intestinal barrier dysfunction. IBD is classically associated with gut accumulation of proinflammatory Th1 and Th17 cells accompanied by insufficient Treg numbers and $\operatorname{Tr} 1$ immune suppression. Inflammatory $\mathrm{T}$ cells guide innate cells to perpetuate a constant hypersensitivity to microbial antigens, tissue injury and chronic intestinal inflammation. Recent studies of intestinal mucosal homeostasis and IBD suggest involvement of innate lymphoid cells (ILCs). These lymphoid-origin cells are innate counterparts of T cells but lack the antigen receptors expressed on B and T cells. ILCs play important roles in the first line of antimicrobial defense and contribute to organ development, tissue protection and regeneration, and mucosal homeostasis by maintaining the balance between antipathogen immunity and commensal tolerance. Intestinal homeostasis requires strict regulation of the quantity and activity of local ILC subpopulations. Recent studies demonstrated that changes to ILCs during IBD contribute to disease development. A better understanding of ILC behavior in gastrointestinal homeostasis and inflammation will provide valuable insights into new approaches to IBD treatment. This review summarizes recent research into ILCs in intestinal homeostasis and the latest advances in the understanding of the role of ILCs in IBD, with particular emphasis on the interaction between microbiota and ILC populations and functions.

Keywords: inflammatory bowel disease; innate lymphoid cells; intestinal homeostasis

\section{Inflammatory Bowel Disease (IBD)}

Inflammatory bowel disease (IBD) is a heterogeneous state of chronic intestinal inflammation comprising two main clinical phenotypes, Crohn's disease (CD) and ulcerative colitis (UC), distinguished by symptoms, disease location and histopathological features [1]. The global incidence of IBD has increased considerably in recent years, with 6.8 million people affected globally in 2017 and an age-standardized prevalence of 84.3 (79.2-89.9) cases per 100,000 population [2]. IBD is characterized by chronic relapsing inflammation within the gastrointestinal tract with acute episodes and intervals of remission [3-6]. Shared clinical features of CD and UC patients include diarrhea, chronic abdominal pain and extraintestinal symptoms such as arthritis, oral ulcers, skin lesions and ophthalmological 
problems [1,7-9]. However, the two clinical manifestations of IBD show some differences in underlying pathology, inflammatory burden and prognosis [1,7-9]. UC is characterized by involvement of the colon, mainly in the mucosal layer, whereas $C D$ patients have patchy lesions throughout the gastrointestinal tract, from the mouth to the anus, characterized by transmural inflammation, fistulae, abdominal abscesses and intestinal obstructions [8-11] (Figure 1).

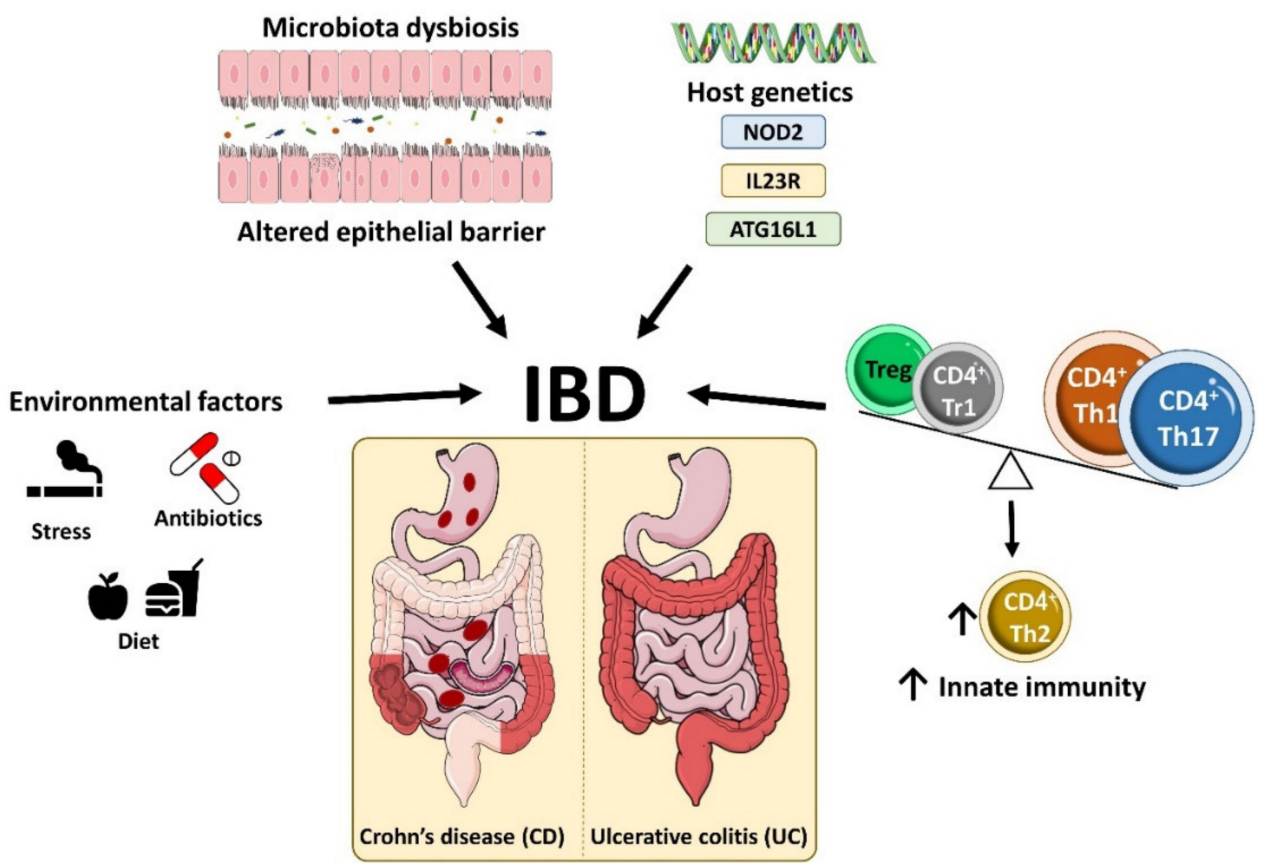

Figure 1. Etiology of inflammatory bowel disease. IBD is a heterogeneous state of chronic intestinal inflammation comprising two main clinical phenotypes, Crohn's disease (CD) and ulcerative colitis (UC), which are distinguished by their symptoms, disease location and histopathological features. IBD arises from the interplay between environment factors, the gut microbiota and immunological factors in genetically susceptible individuals, which promotes intestinal barrier dysfunction, tissue damage and dysregulated innate and adaptive immune responses.

\section{Inflammatory Bowel Disease Etiology and Pathophysiology}

IBD originates from an interplay between the environment, gut microbiota and immunological factors in genetically susceptible individuals, which promotes intestinal barrier dysfunction, tissue damage and dysregulated innate and adaptive immune responses [5,11,12] (Figure 1).

Numerous studies have demonstrated links between IBD and genetic factors. A family history of IBD is a risk factor for developing the disease $[13,14]$, and IBD is also more prominent in monozygotic twin pairs than in dizygotic twin pairs [15]. Genomewide association studies identified more than 200 IBD-associated genes, including genes related to host-mediated responses to the gut microbiota [16]. The first gene variants identified were of the muramyl dipeptide receptor NOD2 (nucleotide binding oligomerization domain containing 2) and were found to be associated with CD in Europeans and Americans $[17,18]$. However, this association was not found in China and Japan, revealing ethnic heterogeneity [19-21]. NOD2, expressed in innate immune cells, recognizes bacterial cell wall elements, and activates the nuclear factor kappa-light-chain-enhancer of activated B cells (NF- $\mathrm{kB}$ ) signaling pathway. CD-susceptible NOD2 variants modify the recognition of bacterial wall components, increasing NF- $\mathrm{kB}$ activation in monocytes [22,23]. Other genes with variant forms showing strong and reproducible associations with $\mathrm{CD}$ are interleukin 23 Receptor (IL23R) gene and the autophagy-related gene ATG16L1 [24]. For example, some ATG16L1 polymorphisms in CD patients increase interleukin (IL-)1 $\beta$ production 
upon activation with NOD2 ligands [25]. This IL-1 $\beta$ potentiates intestinal inflammation by inducing T helper (Th)17 cell differentiation [26] (Figure 1).

A common feature of IBD in all patient categories is the infiltration of intestinal tissue by inflammatory CD4 $\mathrm{T}$ cells $[27,28]$. The predominant gut-infiltrating proinflammatory $\mathrm{T}$ cell populations in IBD are Th1 cells, which express the transcription factor T-bet and the cytokine interferon (IFN-) $\gamma$, and Th17 cells, which express the transcription factor retinoid (RAR)-related orphan receptor (ROR) $\gamma t$ and the cytokine IL-17 [29-34]. Infiltration by these populations is accompanied by an increase in the numbers of GATA-3-expressing IL-5- and IL-13-producing Th2 cells [35,36] and insufficient numbers of immune-suppressing cells, such as Foxp3-expressing T regulatory (Treg) and T regulatory type 1 ( $\operatorname{Tr} 1)$ cells [37-39] (Figure 2). Inflammatory T-cells guide the function of innate cells such as epithelial cells, fibroblasts and phagocytes, thus stimulating a constant hyperresponsiveness to microbial antigens [28] and causing tissue injury and chronic intestinal inflammation [40]. Some studies have reported IBD-associated dysbiosis, but it is still unclear if this is a cause or effect of IBD [41]. Chronic intestinal inflammation thus involves contributions from the intestinal microbiota, alterations to the epithelial intestinal barrier, the activation of immune cell, and reduced immune tolerance to bacteria [42].

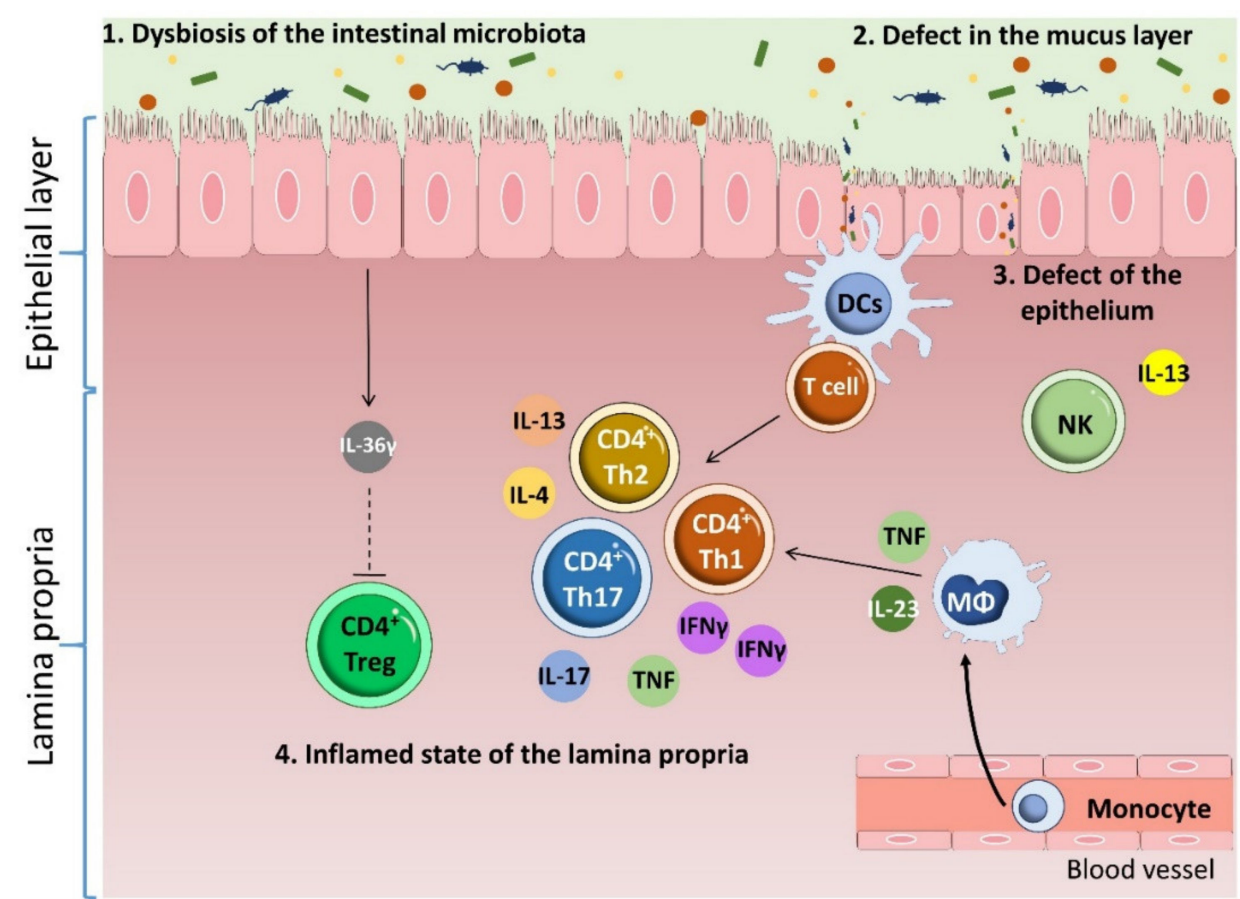

Figure 2. Pathophysiology of inflammatory bowel disease. Multiple factors contribute to IBD. Changes in the microbiota accompanied by thinning of the mucus layer induces a barrier breach that results in defects in the epithelium. Crossing of the barrier by microbiota components induces DC and macrophage activation, which induces infiltration of the intestinal tissue by inflammatory CD4 T cells. IBD patients have an increased content of proinflammatory Th1 and Th17 cells. This infiltration is accompanied by an increase in Th2 cell numbers and insufficient numbers of immune suppressing cells, such as Tregs. Inflammatory T cells guide the function of cells with an innate immune role, such as epithelial cells, fibroblasts and phagocytes, thus stimulating a constant hyperresponsiveness to microbial antigens and causing tissue injury and chronic intestinal inflammation.

\section{Innate Lymphoid Cells (ILCs)}

Recent discoveries have highlighted the role played in intestinal mucosal homeostasis and IBD by innate lymphoid cells (ILCs) [43-48]. ILCs play important roles in antimicrobial defense, and contribute to organ development, tissue protection and regeneration and mucosal homeostasis $[49,50]$. These cells belong to the innate immune response but originate from the same common lymphoid progenitor as lymphocytes [51,52]. Thus, while ILCs 
are the innate counterparts of $\mathrm{T}$ cells, they lack T-cell receptors generated through somatic recombination of antigen specific receptors. ILCs act early in the immune response by replying quickly to signals or cytokines produced by other cells. In contrast, naïve $\mathrm{T}$ cells require longer to act because they must first encounter antigens and undergo clonal proliferation to differentiate into functional and specific effector cells [51,53-57]. Other unique ILC characteristics that differentiate them from lymphocytes are that, unlike intestinal B, $\mathrm{T}$, and natural killer (NK) cells, their intestinal population is not constantly replaced from the circulation [58] and that ILCs constantly produce their representative cytokines and other soluble molecules at steady state, contrasting with the on-demand production by $\mathrm{T}$ cells $[48,59,60]$.

ILCs can be classified into three subgroups according to their developmental pathways, specific key transcription factor, and cytokine expression [51,61-63]: type 1 ILCs (including natural killer (NK) cells and ILC1s), type 2 ILCs (ILC2s), and type 3 ILCs (including ILC3s and lymphoid tissue-inducers (LTis)) (Figure 3). ILC1s, ILC2s, and ILC3s, respectively, share functional similarities with $\mathrm{CD}^{+}$Th1, Th2 and Th17 cells, whereas NK cells have similar roles to $\mathrm{CD}^{+}$cytotoxic $\mathrm{T}$ cells. In addition, ILCs have many exclusive and pleiotropic functions [51,53-57] (Figure 3).

\begin{tabular}{|c|c|c|c|c|c|}
\hline Immune function & Stimuli & Innate cells & $\begin{array}{l}\text { Adaptive } \\
\text { counterpart }\end{array}$ & $\begin{array}{c}\text { Transcriptional factors } \\
\text { and markers }\end{array}$ & Mediators \\
\hline Type 1 immunity & $\begin{array}{l}\text { Tumors, intracellular } \\
\text { microbes (virus, } \\
\text { bacteria, parasites) } \\
\text { IL-12, TNF } \alpha\end{array}$ & & \pm & $\begin{array}{l}\text { T-bet }(h, m) \\
\text { CD127, CD122, NK1.1, } \\
\text { NKp46 } \\
\text { T-bet }(h, m) \text {, Eomes (m) } \\
\text { CD122, NK1.1, NKp46, } \\
\text { NKG2D }\end{array}$ & $\begin{array}{l}\text { IFNy } \\
\text { IFNy, } \\
\text { Granzymes, } \\
\text { Perforin }\end{array}$ \\
\hline Type 2 immunity & $\begin{array}{l}\text { Large extracellular } \\
\text { parasites } \\
\text { Allergens } \\
\text { IL-2, IL-25, IL-33, PGD2, } \\
\text { TL1A and TSLP }\end{array}$ & & & GATA-3, ROR $\alpha$ & $\begin{array}{l}\text { IL-4, IL-5, IL-9, IL- } \\
13 \text {, and GM-CSF }\end{array}$ \\
\hline Type 3 immunity & $\begin{array}{ll}\text { Extracellular } & \text { IL-6 } \\
\text { microbes } & \\
\text { (bacteria, fungi) } & \text { IL-1 } \beta, \\
\text { IL-23 } & \text { IL-2 }\end{array}$ & $\mathrm{NCR}^{+}$ & $\left(\mathrm{CD} 4^{+}\right)$ & RORYT, AHR & $\begin{array}{l}\text { IL-17, GM-CSF } \\
\text { IL-22 }\end{array}$ \\
\hline $\begin{array}{l}\text { Formation of } \\
\text { secondary } \\
\text { lymphoid } \\
\text { structures }\end{array}$ & & & & $\begin{array}{l}\text { RORYT, AHR } \\
\text { CCR6+/-, CD4 }\end{array}$ & $\begin{array}{l}\text { IL-22, IL-17, IgA } \\
\text { and lymphotoxin }\end{array}$ \\
\hline
\end{tabular}

Figure 3. Classification of ILCs. ILCs can be classified into three subgroups: type 1 ILCs, including natural killer (NK) cells and ILC1s, type 2 ILCs (ILC2s) and type 3 ILCs (ILC3s). h: human, m: mouse.

\section{Type 1 ILCs}

ILC1s are characterized by the expression of the $\alpha$ chain of the IL-7 receptor (CD127), whereas NK and ILC1s both express the IL-15 receptor $\beta$ chain and the IL-2 receptor (CD122). NK cells and ILC1s also express NK1.1 (also known as killer cell lectin-like receptor subfamily B member $1 \mathrm{C}$, Klrb1c) and natural cytotoxicity receptor NKp46 receptors. T-bet governs the function and differentiation of human and mouse ILC1s and NK cells, and mouse NK cells are also regulated by Eomes [64-69] (Figure 3). 
NK cells are circulating cells, broadly distributed in the blood and secondary lymphoid and peripheral organs. NK cells are mainly found in the systemic circulation, cord blood, bone marrow, spleen, lungs and throughout the human gut [70]. ILC1s are tissue-resident cells that predominantly reside in mucosal sites and are thus abundant in intestinal tissues and the tonsils $[64,65,68,71]$. ILC1s are also located in the liver, salivary glands, uterus and thymus [47,65,70-73] (Figure 4). NK cells, such as CD8 ${ }^{+} \mathrm{T}$ cells and ILC1s, like Th1 cells respond to intracellular pathogens such as viruses [74,75] and to tumors [76-78] (Figure 3).
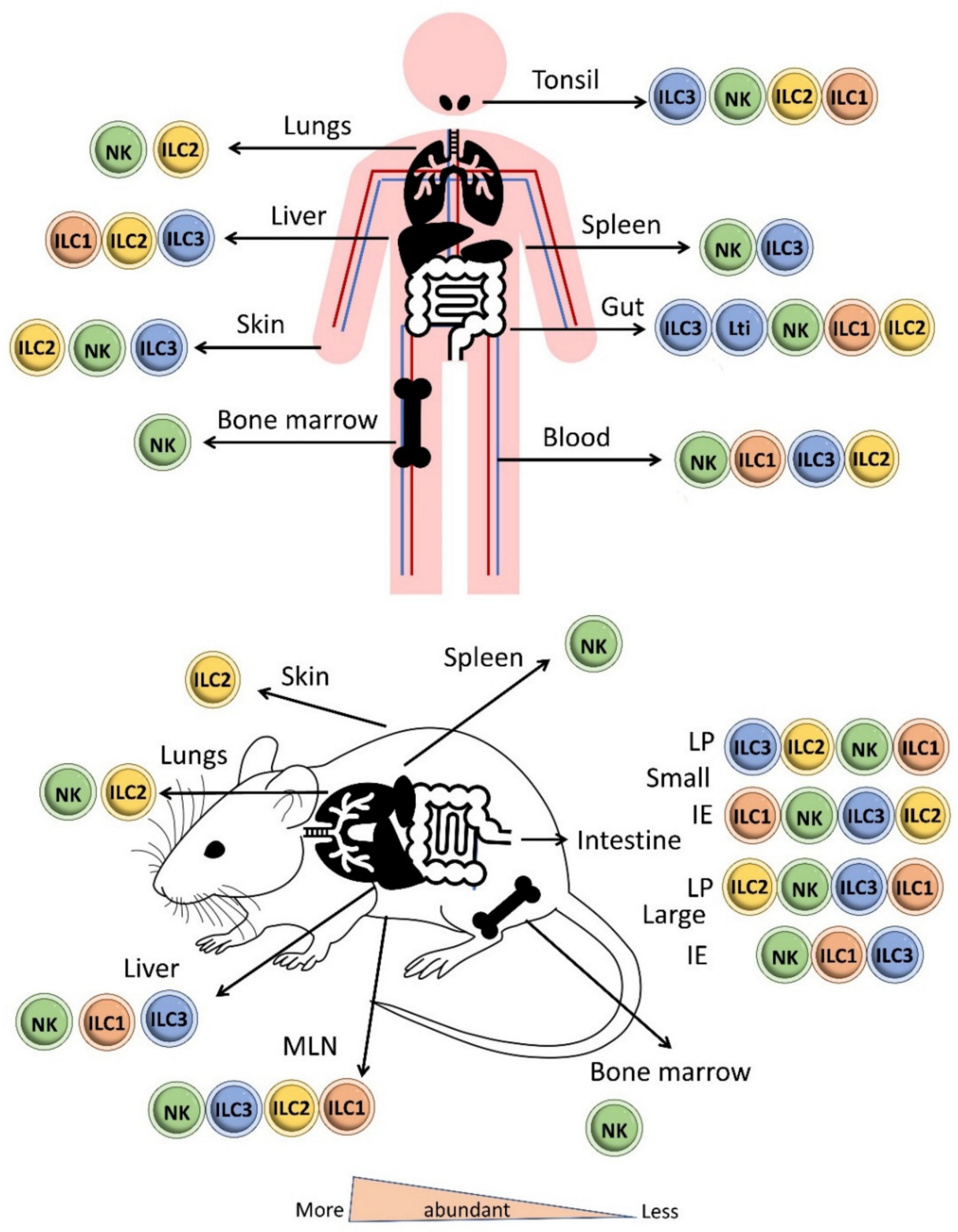

Figure 4. Distribution of ILCs in the body in human and mouse. NKs are circulating cells that are mainly found in the systemic circulation, cord blood, bone marrow, spleen, lungs and throughout the human gut. ILC1s are tissue-resident cells that mainly reside in intestinal tissues and tonsils but are also located in the liver, salivary glands, uterus and thymus. ILC2s are mainly found in adipose tissue, mesenteric lymph nodes, lungs, skin and tonsils. ILC3s are mainly present in mucosal tissue and at low levels in the spleen and liver. LTis cells are predominantly located in intestinal and lymphoid tissues, whereas $\mathrm{NCR}^{+}$ILC3s and $\mathrm{NCR}^{-}$ILC3s are more prominent in the skin and intestinal lamina propria. (LP: Lamina propria; IE: intraepithelial). 
NK cells distinguish target cells by stimulating and repressing the surface receptors NKp46, Natural killer group 2 member D (NKG2D), and in some mouse strains NK1.1. NK cells release IFN- $\gamma$ and exert a cytotoxic effect in early defense against intracellular pathogens through the expression of cytotoxic compounds, the serine protease granzyme $\mathrm{B}$ and the pore-forming protein perforin, which causes apoptosis or osmotic cell lysis of the target cell [68]. NK cells also intervene in tumor immunosurveillance and in the balance of the immune system response by destroying some activated immune cells $[79,80]$. NK cells can be classified as CD56lo NKs and CD56hi NKs [81-83], with CD56lo NKs having a relatively more potent cytolytic activity and a lower capacity to sense and produce cytokines, especially IFN- $\gamma[82,83]$.

ILC1s are broadly noncytotoxic but produce IFN- $\gamma$ in response to IL-12 and tumor necrosis factor (TNF) to target intracellular pathogens such as viruses and bacteria [84-88].

\section{Type 2 ILCs}

ILC2s, the innate counterparts of Th2 cells, play important roles in the defense against large extracellular parasites by recruiting eosinophils and stimulating macrophages, granulocytes, mucus production by goblet cells and smooth muscle contraction [51,54]. ILC2s also intervene in allergen responses, promote airway inflammation and maintain and repair the airway epithelium [89-92]. ILC2s are also able to mount memory responses through a process termed trained immunity, generating efficient recall responses to reinfection [93]. These memory-like ILC2s are also important in response to allergens [94]. In fact, allergenspecific immunotherapy modifies the composition and heterogeneity of ILCs, among other innate immune cells, and brings them to the level found in healthy individuals. [95]

ILC2s produce IL-4, IL-5, IL-9, IL-13 and Granulocyte Macrophage Colony-Stimulating Factor (GM-CSF) upon activation by IL-2, IL-25, IL-33, prostaglandin (PGD)2, TNF-like ligand 1 A (TL1A), and Thymic Stromal Lymphopoietin (TSLP) [53,82,86,96-100]. ILC2 maintenance and function require the expression of the transcription factor GATA3 [101,102], and ILC2 function and differentiation also involves the transcription factors $\mathrm{ROR} \alpha$, transcription factor T cell factor 1 (TCF1), BAF Chromatin Remodeling Complex (Bcl-)11b, ETS1, and Id2 $[103,104]$ (Figure 3$)$. ILC2s are mainly found in adipose tissue, spleen, mesenteric lymph nodes, lung, skin and tonsils [65,71] (Figure 4).

\section{Type 3 ILCs}

The generation and function of ILC3s depend on the expression of ROR $\gamma \mathrm{t}$ and aryl hydrocarbon receptor (AHR) $[105,106]$. ILC3s, like Th17s, promote immunity to extracellular bacteria such as Citrobacter rodentium and fungi and participate in tissue repair [50,51,107-109]. Type 3 ILCs include the LTi cells, natural cytotoxicity receptor (NCR) ${ }^{-}$ ILC3s, and NCR ${ }^{+}$ILC3s. NCR is designated as NKp46 in mice and as NKp44 in humans $[66,69,110,111]$.

During fetal development, LTis play an essential role in the generation of most secondary lymphoid organs, including the lymph nodes and Peyer's patches, by teaching mesenchymal stromal cells to attract and retain hematopoietic cells [69]. LTis also stimulate stromal cells to recruit, retain and activate lymphocytes, as well as participating in the renewal and stimulation of epithelial cell defense and antiapoptotic programs [109,112]. LTis can be classified according to CCR6 expression [61,113]. C-C Motif Chemokine Receptor $6(\mathrm{CCR} 6)^{+}$ILC3s, including embryonic and mature LTi cells, produce IL-22, IL-17, immunoglobulin (Ig)A and lymphotoxin [61,114-116].

$\mathrm{NCR}^{+}$ILC3s resemble Th22 cells, producing IL-22 upon stimulation with IL-1 $\beta$, IL-23, and IL-2. In contrast, $\mathrm{NCR}^{-}$ILC3s resemble Th17 cells in expressing IL-17 and GM-CSF in response to cytokines such as IL-6 [69,116-120]. NCR ${ }^{+}$and $\mathrm{NCR}^{-}$ILC3s are both able to produce IFN- $\gamma$ [113]. 


\section{ILCs and Intestinal Homeostasis}

The gastrointestinal tract is a fundamental organ system for nutrient assimilation that is in constant contact with antigens from the diet, commensal bacteria and pathogens [39]. The intestinal immune system, therefore, needs to be permissive of dietary antigens and microbiota while effective against pathogens [39]. For this reason, the intestine is host to a multitude of organized cellular interactions in which ILCs play a fundamental role in regulating local immunity, inflammation and homeostasis [69]. Distinct ILC populations contribute to intestinal homeostasis in steady state conditions. Along the alimentary tract, the total number of ILCs increases from the oral cavity to the lower gastrointestinal tract, with the highest populations found in the ileum and colon [121].

The human gut contains two major subpopulations of ILC1s: lamina propria ILC1s $\left(\mathrm{CD} 161^{+}, \mathrm{CD}_{127^{+}}, \mathrm{NKp}^{-}\right)$[84] and intraepithelial ILC1s (NKp44 $\left.{ }^{+}, \mathrm{CD}^{2} 13^{+}, \mathrm{CD}^{2} 7^{-}\right)$, which are comparable to classical NK cells in phenotype and cytotoxicity [122] (Figure 5). ILC2s are profuse in the fetal gut but are infrequent in the adult intestine, where they occur in lower number than ILC1s and ILC3s under steady state conditions [123]. ILC3s are mostly found in mucosal tissue and at low levels in the spleen, secondary lymphoid organs and the liver $[65,70,71]$ (Figure 4). LTi cells are predominantly located in intestinal and lymphoid tissues, whereas NCR ${ }^{+}$ILC3s and $\mathrm{NCR}^{-}$ILC3s are more prominent in the skin and intestinal lamina propria $[113,124]$. ILC1s are the major fraction in the upper gastrointestinal tract, whereas ILC3s form the most numerous ILC populations in the ileum and colon [70].

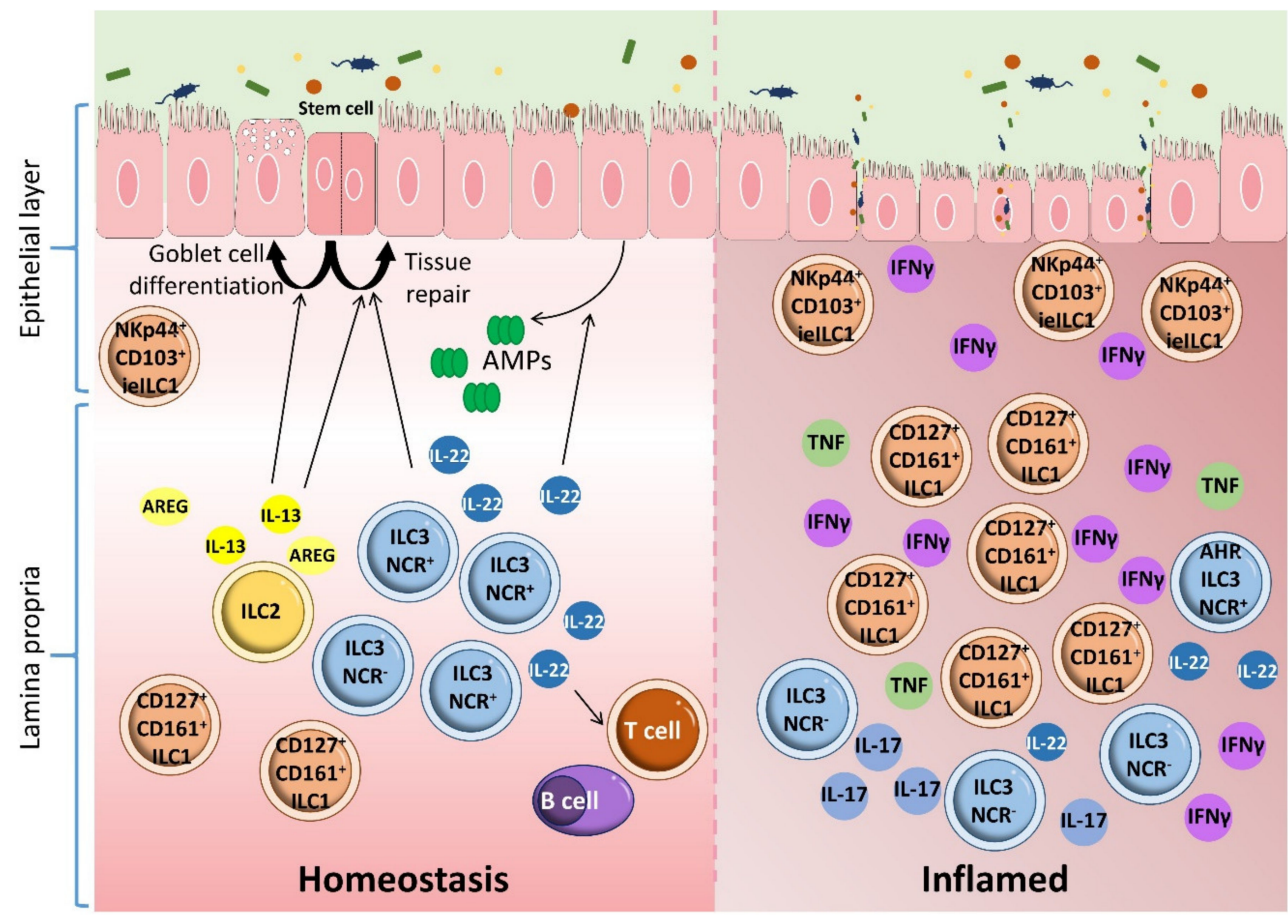

Figure 5. ILCs, homeostasis, and inflammatory bowel disease. There are two major subpopulations of ILC1s in the human gut: lamina propria ILC1s $\left(\mathrm{CD} 161^{+} \mathrm{CD} 127^{+}\right)$and intraepithelial ILC1s (NKp44 $\left.{ }^{+} \mathrm{CD}_{103}{ }^{+} \mathrm{CD} 127^{-}\right)$. ILC2s are present in lower numbers than ILC1s and ILC3s. ILC2s contribute to epithelial barrier maintenance through the production of IL-13, which promotes the differentiation of intestinal epithelial stem cells toward turf cells and goblet cells. ILC2s also maintain intestinal epithelia homeostasis through the production of amphiregulin (AREG). ILC3s maintain gastrointestinal tract homeostasis by producing IL-22. This cytokine activates intestinal epithelial cells to produce antimicrobial peptides, enhances the renewal of epithelial cells, promotes tissue repair and modulates the homeostasis of adaptive immunity. Alteration of the ILC subset profile disturbs intestinal homeostasis and leads to inflammation in the gut. ILC3s and ILC1s are involved in the induction of inflammation and are closely related to IBD pathogenesis. This conclusion is supported by the amplification of intraepithelial IFN- $\gamma$-producing ILC1s in response to IL-12 and IL-15 in the gut of CD patients. This increase is accompanied by a reduction in $\mathrm{NCR}^{+}$ILC3s, enhancing disease severity. 
ILCs, especially ILC3s, maintain gastrointestinal tract homeostasis through the following mechanisms: (1) sensing and interacting with the microbiota, (2) enhancing the renewal of epithelial cells and promoting tissue repair, (3) regulating the activation of intestinal epithelial cells to produce antimicrobial peptides and (4) modulating the homeostasis of adaptive immunity [46] (Figure 5).

The gut microbiota limits colonization by pathogens at barrier tissues through competition and the induction of immune responses. Commensals also favor immune homeostasis through the production of metabolites and their continuous collaboration with host cells [125]. The microbiota and its derived metabolites influence ILCs [126]. The microbiota directly influences ILC3 responses through sensing receptors [126-128]. Through the anerobic fermentation of undigested carbohydrates, the resident microbiota produces short-chain fatty acid (SCFA) end-products, including acetic acid, propionic acid, and butyric acid [129]. Some SCFAs induce ILC3 cell generation and IL-22 production through stimulation of the AKT-STAT3 and ERK-STAT3 signaling pathways [130] (Figure 6). Through their receptor free fatty acid receptor 2 (FFAR2), SCFAs also mediate host defense against Citrobacter rodentium and support tissue repair, as observed in a mouse model of dextran sodium sulfate (DSS)-induced intestinal injury $[129,130]$. IL-22 production by ILC3s is enhanced in germ-free or antibiotic-treated mice [131], and ILC3 generation and IL22 production is limited by addition of butyrate to ILC3s in vitro [132]. Moreover, dietary fiber-derived SCFAs produced by the commensal microbiota support optimal gut proliferation of ILCs, including ILC1, ILC2 and ILC3, by regulating G protein-coupled receptors (GPCRs) [44] (Figure 7a). In allergic asthma, butyrate, but not acetate or propionate, represses production of the type 2 cytokines IL-13 and IL- 5 as well as proliferation and GATA3 expression in mouse and human ILC2s [133]. This inhibitory effect depends on an histone deacetylase (HDAC) suppressive effect rather than action through GPR41 or GPR43 [133], as also observed in ILC2-mediated lung inflammation induced by IL-33 and Alternaria [134]. Further experiments are needed to clarify the specific roles and mechanisms of SCFAs in ILC function.

ILC3s recognize microbial ligands through the engagement of NCRs such as NKp46, NKp44 and NKp30 [135]. In human ILC3s, binding of the natural cytotoxicity receptor NKp44 promotes the production of TNF $\alpha$ and, in combination with IL-1, IL-17 and IL-23 stimulation, enhances the production of IL-22, GM-CSF, IL-2 and TNF $\alpha$ through an NF- $\mathrm{kB}$ and nuclear factor of activated T-cells (NFAT)-dependent mechanism [136] (Figure 6). In addition, bacterial stimulation of NKp44 on ILC3s significantly enhances the proportion of IL-22-producing ILC3s [137].

ILC3s also express Toll-like receptors (TLRs) 1, 2, 5, 6, 7 and 9 (but not 3 and 4). These receptors recognizes pathogen-associated molecular patterns (PAMPs) derived from the gut microbiota [138]. In conjunction with IL-23 or IL-2, TLR2 stimulation in human ILC3s promotes the production of IL-22, IL-13 and IL-5 upon activation of NF- $\mathrm{kB}$ and Janus kinases (JAK) signaling [138] (Figure 6).

In addition to direct regulation, commensal bacteria control ILC3 activation indirectly by modulating myeloid cells and epithelial cells in the intestine $[139,140]$. The mouse intestinal microbiota promotes tissue-resident myeloid-cell production of IL- $1 \beta$, which stimulates ILC3s to produce GM-CSF [139]. This GM-CSF, in turn, stimulates myeloid cells to promote Treg expansion and enhance tolerance [117,139] (Figure 6). Moreover, this microbiota-dependent myeloid-produced IL-1 $\beta$ triggers ILC3s to generate IL-2, which promotes Treg generation and intestinal tolerance to dietary antigens [140]. Tregs prevent ILC3-associated colitis by inhibiting IL-23 and IL-1 $\beta$ production from intestinal-resident C-X3-C Motif Chemokine Receptor $1\left(\right.$ CX3CR1) ${ }^{+}$macrophages, which restrains ILC3-linked IL-22 production [141] (Figure 6). Additionally, CD11 $\mathrm{c}^{+}$myeloid dendritic cells produce IL-23 and IL-1 $\beta$ in response to enteric bacteria and contribute to ILC3 production of IL22 [137]. Stimulation of dendritic-cell TLR5 with the bacterial protein flagellin promotes the generation of IL-23, which drives IL-22 production by ILC3s (Figure 6). 


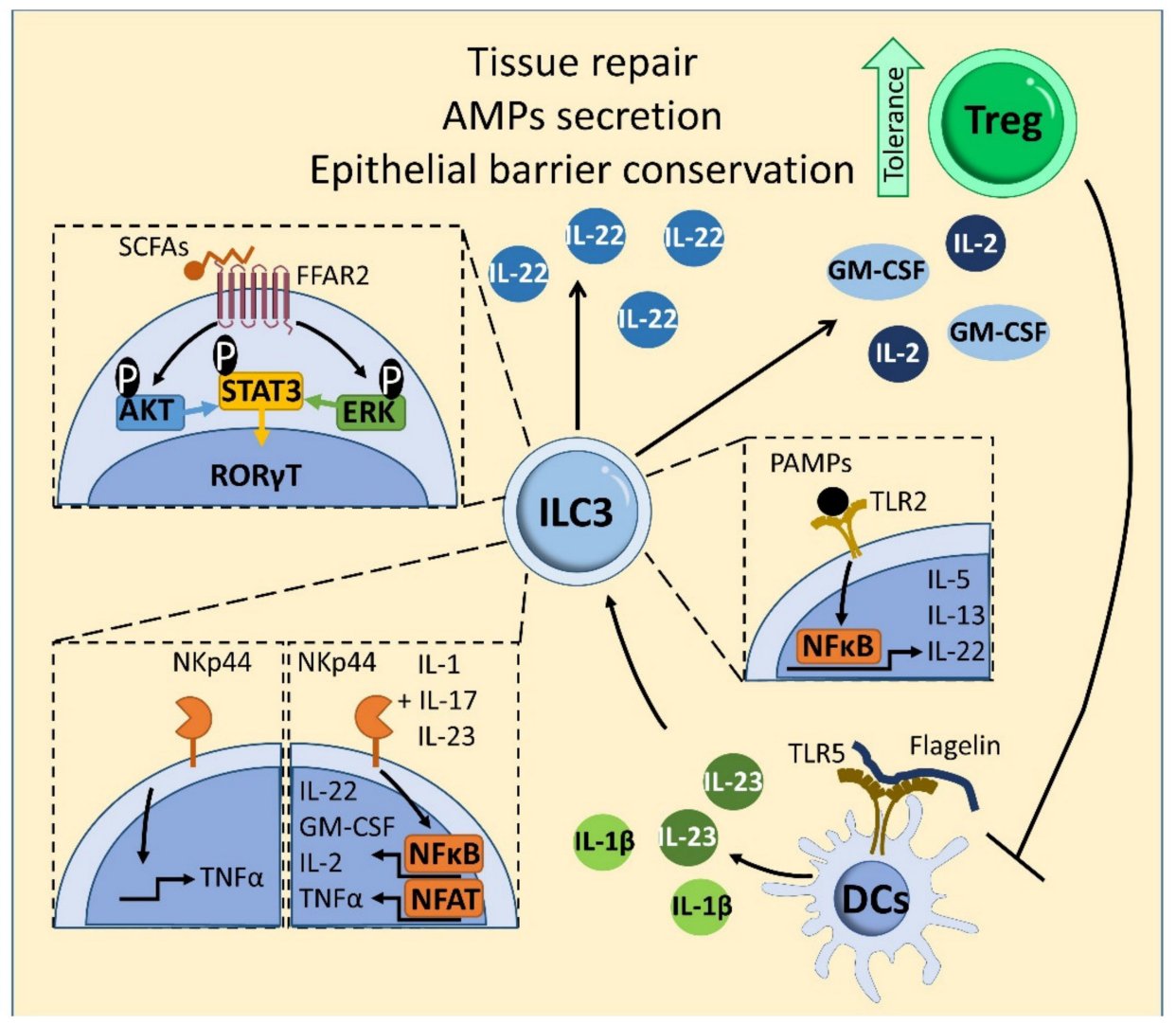

Figure 6. Microbiota-ILC3 interactions in intestinal homeostasis. Some SCFAs are recognized by the receptor FFAR2 on ILC3s, triggering IL-22 cytokine production by stimulating the AKT-STAT3 and ERK-STAT3 signaling pathways. TLR2 stimulation in human ILC3s promotes the production of IL-22, IL-13 and IL-5 upon activation of signaling via NF-KB and JAK (not shown). Stimulation of the TLR5receptor on dendritic cells (DCs) with the bacterial protein flagellin promotes the production of IL-23 and IL-1b, which induces production of IL-22, and IL-2 and GM-CSF by ILC3s, respectively. In human ILC3s, ligation of the natural cytotoxicity receptor NKp44 promotes the production of TNF $\alpha$ by ILC3s and, in combination with IL-1, IL-17 and IL-23, enhances ILC3 production of IL-22, GM-CSF, IL-2 and TNF $\alpha$ in a mechanism mediated by NF- $\mathrm{KB}$ and Nuclear factor of activated T-cells (NFAT) signaling. NKp44 receptor activation also increases the proportion of IL-22-producing ILC3s. IL-22 facilitates intestinal homeostasis by preservation of epithelial barrier function and promoting the secretion of antibacterial peptides (AMPs). IL-2 and GM-CSF contributes to intestinal tolerance mediated by Tregs. Tregs prevent ILC3-associated colitis by inhibiting IL-23- and IL-1 $\beta$-induced IL-22 production.

NK development does not require microbiota; however, NK cell function is altered in the absence of commensal bacteria, evidenced by reduced cytotoxicity and IFN- $\gamma$ production in germ-free or antibiotic-treated mice [68]. In line with this finding, NK cytotoxicity is increased by colonization of germ-free mice with commensals [142], an effect mediated by the actions of dendritic cells and macrophage-derived type-I interferon on IL-15 [143,144]. IL-15 promotes terminal NK cell maturation, thus the commensal microbiota indirectly controls the generation of NK cells [126,145] (Figure 7b). The microbiota also mediates the postnatal transformation of LTi-cell cryptopatches into isolated lymphoid follicles, which support the production of intestinal IgA [146] (Figure 7c). The impact of the microbiota on ILC1 development and function is not well established, except that the absence of microbiota reduces ILC expression of T-bet [113,147] (Figure 7d). 
a)

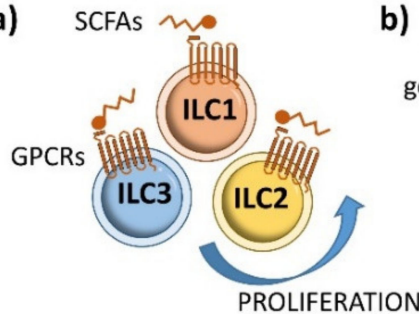

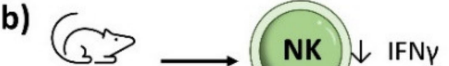

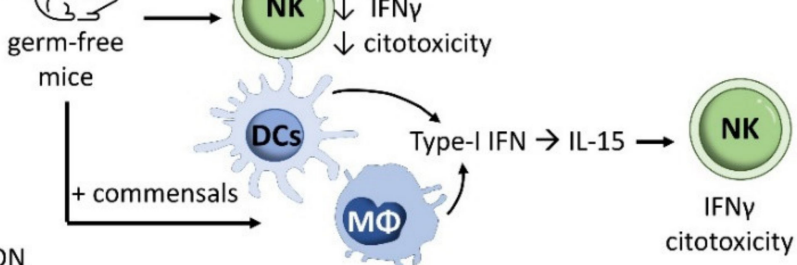

c) Cryptopatches

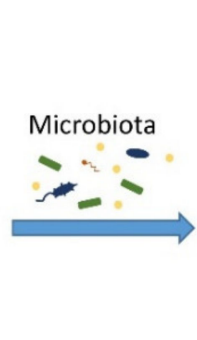

Isolated Lymphoid Follicles (ILF)

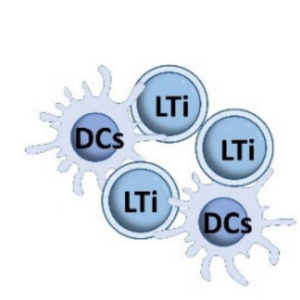

d)

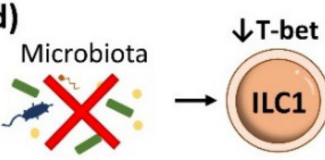

e)

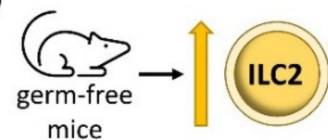

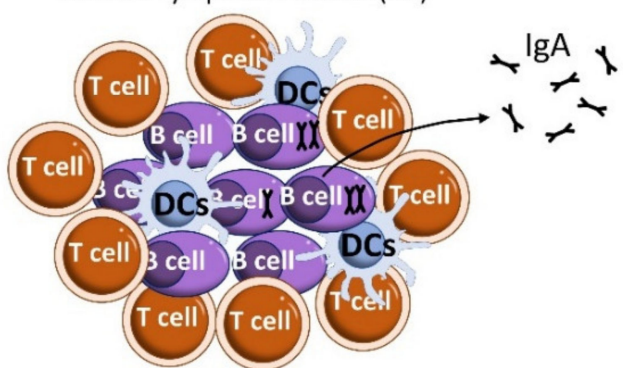

f)

Figure 7. Influence of microbiota in other ILCs in intestinal homeostasis. (a) SCFAs produced by the commensal gut microbiota support optimal proliferation of ILC1, ILC2 and ILC3 populations by regulating G protein-coupled receptors (GPCRs). (b) In the absence of commensal bacteria, NK cells have reduced cytotoxicity and IFN- $\gamma$ production. Colonization of germ-free mice with commensals increases NK cytotoxicity through the effect of dendritic cells and macrophage-derived type-I interferons on IL-15, which promotes NK cell terminal maturation. (c) LTi cells produce cryptopatches, which are transformed into isolated lymphoid follicles in a microbiota-dependent manner, supporting the production of intestinal IgA. (d) The gut microbiota enhances the expression of T-bet in ILCs. (e) The proportion of ILC2s in the gut is increased in the absence of commensal microbiota. (f) The microbiota regulates ILC2 function in the gut by promoting the release of IL-25, which drives ILC2s to improve intestinal barrier function.

ILC2s are the least abundant intestinal ILCs [70]. Germ-free and specific-pathogen-free (SPF) mice show no differences in the number and frequency of ILC2s or the expression of ILC2 markers (the receptors for IL-25 and IL-33, IL-7R $\alpha$, T1/ST2, and c-Kit) [148]. This would suggest that the microbiota is not required for ILC2 development [126]; however, lack of commensal microbiota increases the percentage of ILC2s in the gut [149] (Figure 7e). Microbiota-ILC interactions contribute to the maintenance of a tight and healthy epithelial intestinal barrier. Human ILC2s directly recognize bacteria through the expression of TLR1, TLR4 and TLR6 [150]. Other studies show that the microbiota regulates ILC2 function in the gut by promoting the release of IL-25, which drives ILC2-mediated improvement of the intestinal barrier [131,151] (Figure 7f). The cytokine IL-33 stimulates ILC2s and reduces Clostridium difficile colitis [152], whereas selective genetic abrogation of T-bet in ILCs promotes ILC2 expansion and increases ILC2 activity, resulting in protection against Trichinella spiralis infection and inflammatory colitis [153].

ILC2s also contribute to gut homeostasis and the progression of inflammation through other mechanisms. These include conservation of the epithelial barrier through the production of IL-13, which promotes the differentiation of intestinal epithelial stem cells toward turf and goblet cells. Turf cell differentiation enhances epithelial sensing, whereas goblet cells increase mucus production [151]. ILC2-derived IL-13 favors self-renewal of intestinal epithelial stem cells [154]. ILC2s are stimulated by IL-33, IL-25 and thymic stromal lymphopoietin, as well as eicosane cytokines such as prostaglandin D2 (PGD2) and leukotriene D4 [155]. ILC2s also maintain epithelial homeostasis through the IL-33-dependent production of the growth factor amphiregulin (AREG), which binds to epithelium-expressed 
epidermal growth factor receptor (EGFR) [156]. ILC2-expressed IL-13 promotes cup-cell hyperplasia, modifying the intestinal epithelial barrier and promoting acidophilic cell proliferation by stimulating the production of IL-5 and IL-9 [157]. In contrast, T-bet-producing ILCs like ILC1s increase intestinal barrier permeability through the action of IFN- $\gamma$ and TNF- $\alpha[158,159]$.

ILC3s also contribute to intestinal homeostasis by mechanisms independent of microbiota interaction. ILC3-derived IL-22 has been linked to the induction of several factors that promote intestinal homeostasis and preserve the epithelial the barrier function, such as tight and gap junction proteins, mucins and cytokine receptors [160]. Moreover, reduced gut IL-22 production impairs microbiota symbiosis [109,161]. IL-22, mostly derived from ILC3s, also stimulates gut epithelial cells to secrete antibacterial peptides that promote long-term tolerance to diet-derived antigens [162]. This action is mediated by the activation of IL-22 receptors expressed on nonhematopoietic intestinal cells, primarily intestinal epithelial cells [163]. IL-22 stimulation of Paneth cells promotes production of the antimicrobial proteins Reg3b, Reg3y, S100A8 and S100A9 [164].Moreover, ILC3-derived IL-22 increases the proliferation of Lgr5 ${ }^{+}$intestinal epithelial stem cells [165]. ILC3-derived IL-22 and lymphotoxin induce fucosyl transferase (Fut2) expression in epithelial cells, favoring the fucosylation of intestinal epithelial cells [166]. Epithelial fucose is used as a dietary carbohydrate by commensal bacteria, establishing a mechanism of host-microbiota symbiosis that contributes to intestinal homeostasis $[167,168]$. Through their intrinsic expression of major histocompatibility complex class II (MHC-II), MHC-II+ CCR6 ${ }^{+} \mathrm{ILC}^{+}$s contribute to the maintenance of intestinal immune tolerance by promoting the apoptosis and deletion of $\mathrm{CD}^{+} \mathrm{T}$ cells specifically targeting commensal bacteria in the lamina propria $[169,170]$.

\section{ILCs and Inflammatory Bowel Disease}

IBD is associated with intestinal alterations and dysbiosis [171,172]. Together with other immune cell populations, ILCs participate in IBD pathogenesis through interaction with the microbiota, modulation of epithelial barrier integrity, and the production of cytokines such as IL-22 and IL-17 [43,45,47,57,118,173,174] (Figure 5). Aberrant alterations to the ILC population balance disturb intestinal homeostasis, leading to gut inflammation. IBD and gut inflammation are closely linked to the balance between ILC1s and ILC3s (Figure 5). For example, the intraepithelial IFN- $\gamma$-producing ILC1 population is expanded in CD patients in response to IL-12 and IL-15 [84,122], and a similar alteration is seen in antiCD40-induced colitis in Recombination activating gene $(\operatorname{Rag} 1)^{-/-}$mice [122]. This increase is accompanied by a reduction in $\mathrm{NCR}^{+}$ILC3s, increasing disease severity $[84,122,175]$. The ILC population in the lamina propria of inflamed tissues from CD patients is skewed toward the CD127 ${ }^{+}$ILC1 subset [84]. These CD127 ${ }^{+}$ILC1s produce high amounts of IFN- $\gamma$ in response to IL-12 and IL-18 [83].

Not all ILC3 populations are reduced in IBD. ILCs from CD patients have augmented gene expression of some ILC3s cytokines, transcription factors and cytokine receptors such as IL-12A and IL-22, RORC and AHR, and IL23R [5,176]. IL-23 induces ILC3 expression of IL-17 and IL-22 [49,111,112]. Experiments in mouse colitis models have linked IL-23responsive $\mathrm{NCR}^{-}$ILC3s to the development IBD through the production of IL-17A, IL-22, and IFN- $\gamma[177,178]$. IL-23-reactive ILC3s have also been detected in human mucosaassociated lymphoid tissue, including intestinal Peyer's patches and tonsils [50]. Unlike ulcerative colitis patients, CD patients have elevated expression of IL-17A and IL-17F in mucosal ILCs [176]. In an anti-CD4 and anti-CD90 antibody-depleting mouse colitis model, IL-6 was found to contribute to the activation and production of IL-17A, IL-22 and IFN- $\gamma$ in intestinal ILC3s, a finding confirmed in isolated lamina propria cells from IBD patients [119]. Intestinal ILCs, including ILC3s, enter and exit cryptopatches in a highly dynamic process. During colitis, ILC3s mobilize from cryptopatches and initiate inflammatory immune cascades that result in intestinal inflammation [120].

In homeostasis, ILC3-derived IL-22 binds to the IL-22R to trigger the production and maintenance of IL-18 mRNA and promote IL-18 signaling in epithelial cells. In the mouse, 
IL-22 promotes IL-18 signaling in epithelial cells, and impaired IL-18 strengthens intestinal inflammation, harming the intestinal barrier and producing mucosal inflammation [179]. CD patient mucosa contains a reduced number of IL-22-producing $\mathrm{NCR}^{+}$ILC3s [84], and the subsequent reduction in IL-22 may compromise barrier integrity and contribute to IBD development [180]. IBD patients also have reduced levels of regenerating isletderived protein (Reg)III $\gamma$, RegIIIb, Fut2 and mucin protein Muc2 [162,166], in addition to reduced expression of the tight junction protein claudin-2 and impaired regeneration of intestinal epithelial cells $[119,181]$. ILC3s express high levels of the receptor for TL1A, death receptor 3 (DR3). DR3 antibody ligation exacerbates colitis by triggering ILC3 production of GM-CSF via stimulation of the p38 MAPK pathway, resulting in the accumulation of

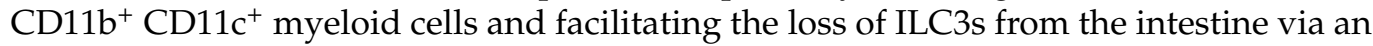
IL-23-dependent mechanism [182]. Consequently, an antibody-mediated DR3 blockade ameliorates colitis, possibly by repressing the harmful effects of ILC3s [182]. In summary, $\mathrm{NCR}^{+}$ILC3s, important for maintaining intestinal homeostasis by producing IL-22, are reduced in IBD, whereas IL-17-producing $\mathrm{NCR}^{-}$ILC3s contribute to disease development.

Like ILC1s, gut NK cells suppress infection but enhance inflammation and $\operatorname{IBD}[79,83,183,184]$. Spontaneous intestinal inflammation is related to high endoplasmic reticulum stress in intestinal epithelial cells. NK cells promote endoplasmic reticulum stress in intestinal epithelial cells by increasing expression of NKG2D and worsen intestinal inflammation by recognizing and killing stressed intestinal cells [185]. NK cell numbers are increased in the lamina propria of the colon of $\mathrm{CD}$ patients and promote $\mathrm{CD}$ by facilitating $\mathrm{CD}^{+} \mathrm{T}$ cell proliferation and Th17 differentiation $[186,187]$. The intestinal mucosa of CD patients has a disrupted balance between NKp44 $4^{+}$and NKp46 ${ }^{+} \mathrm{NK}$ cells [188]. NKp46 $6^{+}$ NK cells may mediate CD by producing IFN- $\gamma$, which activates intestinal inflammatory macrophages in CD-patient intestinal mucosa [188]. Primary sclerosing cholangitis, an idiopathic chronic hepatobiliary-system disorder linked to UC, is associated with increased numbers of IFN- $\gamma$-producing ILC1s [189].

Less is known about the role in IBD played by ILC2s. Treatment with IL-33 or transfer of ILC2s ameliorates mouse intestinal inflammation through an AREG-dependent mechanism [156]. However, IL-33 is increased in the intestinal mucosa of IBD patients, enhancing colitis [190,191]. Moreover, ILC2 numbers are higher in inflamed regions of UCpatient intestine than in noninflamed regions or the intestines of healthy individuals [175]. IL-13 ${ }^{+}$ILC2 numbers are increased in a mouse model of oxazolone-induced colitis [192], suggesting that ILC2s may have a proinflammatory action in UC.

ILC2 activation is evident in CD patient blood from the elevated levels of the IBD markers SLAMF1 (signaling lymphocytic activation molecule family member 1) and human leukocyte antigens (HLA-)DR [16,193], the latter related to the capacity of ILCs to mediate antigen presentation [190]. In CD patients with active disease, SLAMF1+ ILC2 frequency correlates negatively with disease severity and SLAMF1 ${ }^{+}$ILC2s appear to represent a mature population that produces IL-13 and high levels of prostaglandin D2 receptor 2 (PTGDR2/CRTH2), CD161, and GATA3 [194].

ILC2s participate in IBD through their ability to sense microbiota, be stimulated by cytokines and maintain the intestinal barrier. The early IL-33-dependent expansion of ILC2s in CD is driven by activation of the intracellular pattern recognition receptor NOD2, as evidenced in gut-derived ILC2s from CD patients [195] and SAMP1/YitFC (SAMP) mice, a mouse strain that spontaneously develops a progressive, chronic intestinal inflammation similar to CD (reviewed in [196]). NOD2 detects muramyl dipeptide, a peptidoglycan byproduct found in cell walls of both gram-positive and gram-negative bacteria. ILC2s also regulates important functions during early immune responses through the expression of C-C motif chemokine receptor 8 (CCR8), the receptor for CC chemokine ligand 1 (CCL1)/T cell activation specific gene 3 (TCA3) $[197,198]$. CCL1-CCR8 signaling is a key mediator of monocyte and lymphocyte chemoattraction and is implicated in Th2 and Treg-mediated inflammatory diseases [199-203]. CCR8 signaling protects mice against acute intestinal damage through the action of a subgroup of IFN $\gamma$-producing ILCs in a DSS mouse model 
of colitis; however, it remains to be determined whether these cells are proper ILC2s, ILC1s or Tbet ${ }^{+}$exILC3s [204].

ILC2s contribute to the maintenance of intestinal barrier integrity through indirect mechanisms. ILC2s express the surface inhibitory receptor killer-cell lectin like receptor G1 (KLRG1), which promotes ILC2 activity by activating GATA-3 [205]. In a DSS mouse model of colitis, KLRG1 was inhibited as a result of increased miR-21a-5p content in M1macrophage-derived exosomes; the resulting decrease in E-cadherin expression weakened intestinal barrier integrity [206] and aggravated IBD. In addition, ILC2s release IL-13 in response to IL-25 released from Tuft cells activated by berberine, an isoquinoline alkaloid extracted from Coptis chinensis that acts on the bitter taste receptor TAS2R. The ILC2derived IL-13 triggers the differentiation of intestinal stem cells into Turf and goblet cells, which repair injured intestine [207]. While these studies go some way to clarifying the role of ILC2s in IBD, much further work is needed to fully define how ILC2s contribute to immune impairment and protection in IBD.

The altered ILC population profile in IBD is a reflection of ILCs plasticity (Figure 8). In the inflamed intestinal mucosa of CD patients, the numbers of CD127 ${ }^{+} \mathrm{ILC} 1$ is increased at the cost of a decline in ILC3s [208]. This plasticity appears to be linked to downregulation of RORC, upregulation of TBX21 and the production of IFN- $\gamma$ upon prolonged exposure to the type 1 polarizing cytokines IL-2, IL-12 and IL-15 [69,84,209]. ILC3 conversion to the ILC1 phenotype is reversible, and differentiation of ILC1s to ILC3s is driven by IL-23, IL-2, IL-1 $\beta$, and retinoic acid [84,208]. ILC1-to-ILC3 differentiation involves IL-23-mediated activation of STAT3 in CD117- NKp44- type1 ILCs, and this action was linked to the positive correlation found between STAT3 rs744166 risky allele " $\mathrm{A}$ " and disease severity in a cohort of CD patients [210]. STAT3-induced modulation of ILC3 IL-22 production also protects the mouse intestine from infection [211,212]. Interconversion between ILC3s and ILC1s also involves a contribution from dendritic cells. CD14 ${ }^{-}$DCs mediate the transformation of ILC1s into ILC3s in vivo by promoting the expression of c-kit and NKp44, whereas CD14 ${ }^{+}$ DCs are implicated in the transformation of $\mathrm{NCR}^{+}$ILC3s into ILC1s [208].

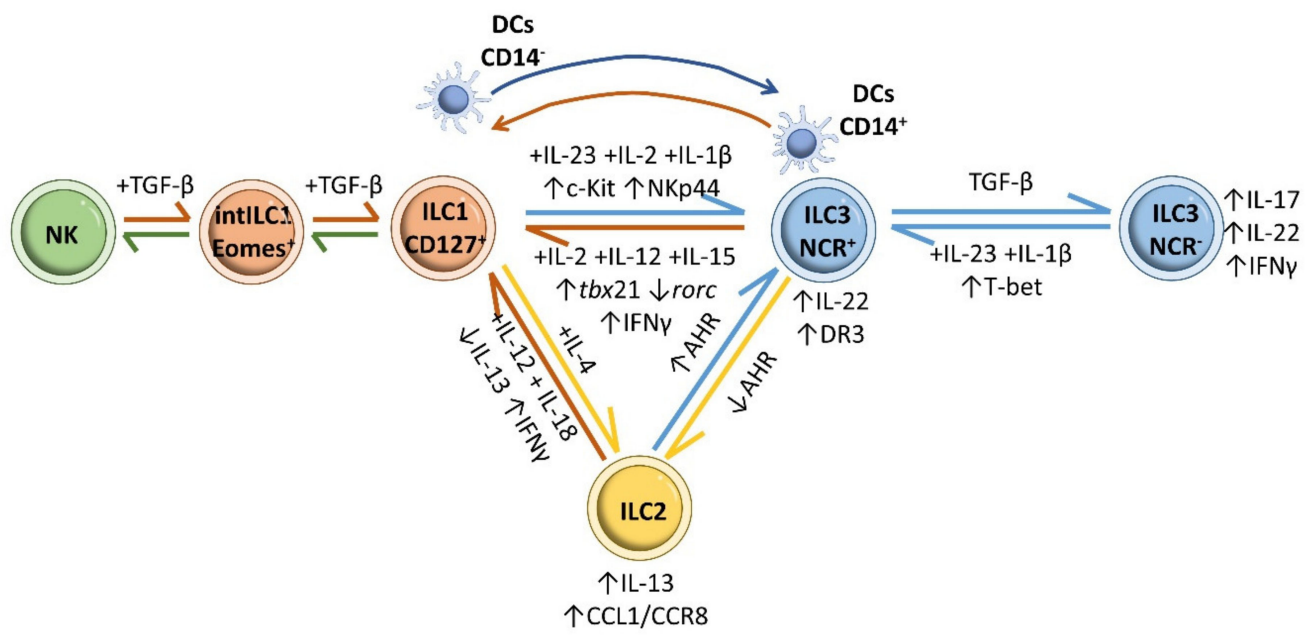

Figure 8. ILC plasticity. Prolonged exposure of ILC3s to the type 1 polarizing cytokines IL-2, IL-12 and IL-15 induces their conversion to $\mathrm{CD} 127^{+}$ILC1 cells, with downregulation of RORC, upregulation of TBX21 and IFN- $\gamma$ production. Reverse differentiation of ILC1s to ILC3s is driven by IL-23, IL-2 and IL-1 $\beta$. Moreover, CD14- DCs mediate the transformation of ILC1s into ILC3s in vivo by promoting synthesis of c-kit and NKp44 in ILC1s, whereas CD14 ${ }^{+}$DCs are implicated in the transformation of $\mathrm{NCR}^{+}$ILC3s into ILC1s. IL-23 and IL-1 $\beta$ stimulation induces the conversion of NCR ${ }^{-}$ILC3s into $^{-}$ the more proinflammatory $\mathrm{NCR}^{+}$ILC3 subset through T-bet upregulation. The reverse differentiation from $\mathrm{NCR}^{+}$ILC3s to $\mathrm{NCR}^{-}$ILC3s is promoted by high levels of TGF- $\beta$. Removal of AHR enriches the effect of intestinal ILC2s, whereas increased AHR expression restrains ILC2 function while increasing ILC3 function. Treatment with IL-12 and IL-18 reduces IL-13 expression in ILC2s, shifting them to an IL-13 ${ }^{-}$IFN- $\gamma^{+}$ILC1 phenotype. ILC2-derived ILC1s can revert to ILC2s in response to IL-4. NK cells (CD49a ${ }^{-}$CD49b ${ }^{+}$Eomes $^{+}$) differentiate into intermediate type 1 innate lymphoid (intILC1, $\mathrm{CD} 49 \mathrm{a}^{+} \mathrm{CD}_{4} 9 \mathrm{~b}^{+}$Eomes $^{+}$) populations and ILC1s $\left(\mathrm{CD} 49 \mathrm{a}^{+} \mathrm{CD} 49 \mathrm{~b}^{-}\right.$Eomes $\left.^{\text {int }}\right)$ in response to cytokine and TGF- $\beta$ signaling. 
IL-23 is also implicated in the conversion of $\mathrm{NCR}^{-}$ILC3s into the more proinflammatory $\mathrm{NCR}^{+}$ILC3 subset via T-bet upregulation during Typhoid bacillus infection in mice $[84,113]$. IL-23- ${ }^{-}$and IL-1 $\beta$-induced transformation of NCR ${ }^{-}$ILC3s into NCR ${ }^{+}$ILC3s has also been reported in vitro in cells isolated from human tonsils and fetal gut [84], and in cells isolated from the skin of psoriasis patients [213]. NCR ${ }^{-}$ILC3-to-NCR ${ }^{+}$ILC3 differentiation appears to depend on sustained Notch signaling [214,215]. The reverse transformation, from $\mathrm{NCR}^{+}$ILC3s to $\mathrm{NCR}^{-}$ILC3s, is promoted by high levels of TGF$\beta$, countering the effects of Notch [215]. An active equilibrium between $\mathrm{NCR}^{+}$ILC3s and $\mathrm{NCR}^{-}$ILC3s is essential for ensuring a balance between antibacterial immunity and homeostasis maintenance in the intestine; disruption of this balance promotes IBD $[45,216]$.

In an inflammatory environment, ILC2s can convert to some or all of the typical ILC1 and ILC3 phenotypes [157]. The frequency of IL-13-producing ILC2s is increased in the intestinal mucosa of CD patients, and in vitro experiments show that IL-12 and IL-18 promote the conversion of ILC2s into ILC1s $[47,217,218]$. Likewise, removal of AHR enriches the effect of intestinal ILC2s and potentiates anti-helminth immunity, whereas AHR activation restrains ILC2 function while increasing ILC3 action, thus supporting antibacterial immunity [219]. It is likely that ILC2-ILC3 interchange triggered by changes in intestinal AHR expression impairs the intestinal immune response in IBD [45]. As with ILC3s and ILC1s, interconversion between ILC2s and ILC1s is bidirectional: ILC2-derived ILC1s can revert to ILC2s in response to IL-4 [220,221].

Plasticity has also been reported in NK-ILC1s in a tumor microenvironment. NK cells $\left(\mathrm{CD} 49 \mathrm{a}^{-} \mathrm{CD} 49 \mathrm{~b}^{+}\right.$Eomes $\left.^{+}\right)$differentiate into intermediate type 1 innate lymphoid cells (intILC1, CD49a ${ }^{+}$CD49b ${ }^{+}$Eomes $\left.^{+}\right)$and ILC1 $\left(C D 49 a^{+}\right.$CD49b $b^{-}$Eomes $\left.{ }^{\text {int }}\right)$ cells in response to cytokine and TGF- $\beta$-signaling [222,223].

In summary, in steady state conditions, ILC3s constitute the major intestinal ILC population, but during active inflammation, IFN- $\gamma$-producing ILC1s and IL-17-producing ILC3s increase, while IL-22-producing ILC3s decrease. This redistribution is linked to increased disease severity.

\section{Conclusions}

The intestinal epithelium has to facilitate nutrient absorption while at the same time impeding the entry of pathogens and toxins. In addition, the gut needs to support a symbiotic interaction with commensal bacteria that promotes their proabsorption activity while keeping them in the intestinal lumen. The intestinal immune system is thus in contact with antigens from food, pathogens and commensal bacterial. The ability to discern between helpful and injurious signals, and to maintain intestinal homeostasis, depends on highly controlled, multicellular processes. ILC subpopulations are important mediators of intestinal homeostasis and play protective and pr-inflammatory roles in IBD. ILCs exert their protective function by controlling the microbial niche and by regulating epithelial barrier maintenance and repair. In contrast, ILCs cause inflammation by releasing cytokines and modulating the innate and adaptive immune responses. ILCs directly and indirectly sense the microbiota, which influences the ILC-mediated immune response; gut bacteria and ILCs modify each other bidirectionally. Alterations to the relative proportions of the different ILC subpopulations are linked to ILC interpopulation transformations and determine the origin, maintenance or prevention of disease. The development of new treatments for IBD will require detailed knowledge of the mechanisms that determine changes to ILC subpopulation frequencies and function, and how these populations mediate their protective and inflammatory effects.

Author Contributions: Conceptualization, J.M.G.-G.; writing, figure design, and editing, A.S., B.H.-F., R.G.-B., C.M., C.R. and J.M.G.-G. All authors have read and agreed to the published version of the manuscript.

Funding: This work was supported by grants from the Instituto de Salud Carlos III (ISCIII) (PI17/01395, PI20/00306) and EuroCellNet COST Action (CA15214) with co-funding from the European Regional 
Development Fund (ERDF) "A way to build Europe". The CNIC is supported by the ISCIII, the Ministerio de Ciencia, Innovación y Universidades (MCNU), and the Pro CNIC Foundation. J.M.G.-G. is supported by the ISCIII I3 SNS Program, imas12, the Comunidad de Madrid, and the Universidad Autonoma de Madrid (UAM); R.G.-B. by imas12 and the ISCIII; B.H.-F. and R.G.-B. by the UAM and the MCNU FPU program (FPU18/00895, FPU19/01774); A.S. by Universidad Francisco de Vitoria and imas12; and C.M. by the Comunidad de Madrid YEI program (PEJ-2020-TL/BMD-17604).

Institutional Review Board Statement: Not applicable.

Informed Consent Statement: Not applicable.

Acknowledgments: The authors thank S. Bartlett for English editing. A.S., R.G.-B. and B.H.-F. contributed equally to this manuscript. Authors thank Servier Medical Art for the creation of a great repertoire of medical images, under a CC BY 3.0 Unported License.

Conflicts of Interest: The authors declare no conflict of interest.

$\begin{array}{ll}\text { Abbreviations } \\ \text { AHR } & \text { Aryl hydrocarbon receptor } \\ \text { CCL1 } & \text { C-C chemokine ligand 1 } \\ \text { CCR8 } & \text { C-C motif chemokine receptor } 8 \\ \text { CD } & \text { Crohn's disease } \\ \text { IBD } & \text { Inflammatory bowel disease } \\ \text { ILCs } & \text { Innate lymphoid cells } \\ \text { EGFR } & \text { Epidermal growth factor receptor } \\ \text { Fut2 } & \text { Fucosyl transferase } 2 \\ \text { GPCRs } & \text { G protein-coupled receptors } \\ \text { NCR } & \text { Natural cytotoxicity receptor } \\ \text { NK } & \text { Natural killer } \\ \text { NOD2 } & \text { Nucleotide binding oligomerization domain containing } 2 \\ \text { LTis } & \text { Lymphoid tissue-inducers } \\ \text { PAMPs } & \text { Pathogen-associated molecular patterns } \\ \text { PGD2 } & \text { Prostaglandin D2 } \\ \text { PTGDR2 } & \text { Prostaglandin D2 receptor 2 } \\ \text { ROR } \gamma \text { t } & \text { RAR-related orphan receptor gamma t } \\ \text { SCFAs } & \text { Short-chain fatty acids } \\ \text { SLAMF1 } & \text { Signaling lymphocytic activation molecule family member 1 } \\ \text { SPF } & \text { Specific-pathogen-free } \\ \text { Th } & \text { T-helper } \\ \text { TL1A } & \text { TNF-like ligand 1 A } \\ \text { TLRs } & \text { Toll-like receptors } \\ \text { Treg } & \text { T regulatory } \\ \text { Tr1 } & \text { T regulatory type 1 } \\ \text { UC } & \text { Ulcerative colitis } \\ \end{array}$

\section{References}

1. Satsangi, J.; Silverberg, M.S.; Vermeire, S.; Colombel, J.F. The Montreal classification of inflammatory bowel disease: Controversies, consensus, and implications. Gut 2006, 55, 749-753. [CrossRef] [PubMed]

2. Global burden of inflammatory bowel disease 2017 Collaborators. The global, regional, and national burden of inflammatory bowel disease in 195 countries and territories, 1990-2017: A systematic analysis for the Global Burden of Disease Study 2017. Lancet Gastroenterol. Hepatol. 2020, 5, 17-30. [CrossRef]

3. Peloquin, J.M.; Goel, G.; Villablanca, E.J.; Xavier, R.J. Mechanisms of pediatric inflammatory bowel disease. Annu. Rev. Immunol. 2016, 34, 31-64. [CrossRef]

4. Liu, T.C.; Stappenbeck, T.S. Genetics and pathogenesis of inflammatory bowel disease. Annu. Rev. Pathol. 2016, 11, 127-148. [CrossRef]

5. Torres, J.; Mehandru, S.; Colombel, J.F.; Peyrin-Biroulet, L. Crohn's disease. Lancet 2017, 389, 1741-1755. [CrossRef]

6. Ungaro, R.; Mehandru, S.; Allen, P.B.; Peyrin-Biroulet, L.; Colombel, J.F. Ulcerative colitis. Lancet 2017, 389, 1756-1770. [CrossRef] 
7. Cleynen, I.; Gonzalez, J.R.; Figueroa, C.; Franke, A.; McGovern, D.; Bortlik, M.; Crusius, B.J.; Vecchi, M.; Artieda, M.; Szczypiorska, M.; et al. Genetic factors conferring an increased susceptibility to develop Crohn's disease also influence disease phenotype: Results from the IBDchip European Project. Gut 2013, 62, 1556-1565. [CrossRef]

8. Louis, E.; van Kemseke, C.; Reenaers, C. Necessity of phenotypic classification of inflammatory bowel disease. Best. Pract. Res. Clin. Gastroenterol. 2011, 25, S2-S7. [CrossRef]

9. Levine, A.; Griffiths, A.; Markowitz, J.; Wilson, D.C.; Turner, D.; Russell, R.K.; Fell, J.; Ruemmele, F.M.; Walters, T.; Sherlock, M.; et al. Pediatric modification of the Montreal classification for inflammatory bowel disease: The Paris classification. Inflamm. Bowel Dis. 2011, 17, 1314-1321. [CrossRef]

10. North American Society for Pediatric Gastroenterology, Hepatology, and Nutrition; Colitis Foundation of America; Bousvaros, A.; Antonioli, D.A.; Colletti, R.B.; Dubinsky, M.C.; Glickman, J.N.; Gold, B.D.; Griffiths, A.M.; Jevon, G.P.; et al. Differentiating ulcerative colitis from Crohn disease in children and young adults: Report of a working group of the North American Society for Pediatric Gastroenterology, Hepatology, and Nutrition and the Crohn's and Colitis Foundation of America. J. Pediatr. Gastroenterol. Nutr. 2007, 44, 653-674.

11. Choy, M.C.; Visvanathan, K.; de Cruz, P. An Overview of the innate and adaptive immune system in inflammatory bowel disease. Inflamm. Bowel Dis. 2017, 23, 2-13. [CrossRef]

12. De Souza, H.S.P.; Fiocchi, C.; Iliopoulos, D. The IBD interactome: An integrated view of aetiology, pathogenesis and therapy. Nat. Rev. Gastroenterol. Hepatol. 2017, 14, 739-749. [CrossRef]

13. Parkes, M.; Jewell, D. Ulcerative colitis and Crohns disease: Molecular genetics and clinical implications. Expert Rev. Mol. Med. 2001, 2001, 1-18. [CrossRef]

14. Farmer, R.G.; Michener, W.M.; Mortimer, E.A. Studies of family history among patients with inflammatory bowel disease. Clin. Gastroenterol. 1980, 9, 271-277. [CrossRef]

15. Zhang, H.; Massey, D.; Tremelling, M.; Parkes, M. Genetics of inflammatory bowel disease: Clues to pathogenesis. Br. Med. Bull. 2008, 87, 17-30. [CrossRef]

16. Liu, J.Z.; van Sommeren, S.; Huang, H.; Ng, S.C.; Alberts, R.; Takahashi, A.; Ripke, S.; Lee, J.C.; Jostins, L.; Shah, T.; et al. Association analyses identify 38 susceptibility loci for inflammatory bowel disease and highlight shared genetic risk across populations. Nat. Genet. 2015, 47, 979-986. [CrossRef] [PubMed]

17. Cho, J.H. The Nod2 gene in Crohn's disease: Implications for future research into the genetics and immunology of Crohn's disease. Inflamm. Bowel Dis. 2001, 7, 271-275. [CrossRef] [PubMed]

18. Bonen, D.K.; Ogura, Y.; Nicolae, D.L.; Inohara, N.; Saab, L.; Tanabe, T.; Chen, F.F.; Foster, S.J.; Duerr, R.H.; Brant, S.R.; et al. Crohn's disease-associated NOD2 variants share a signaling defect in response to lipopolysaccharide and peptidoglycan. Gastroenterology 2003, 124, 140-146. [CrossRef] [PubMed]

19. Economou, M.; Trikalinos, T.A.; Loizou, K.T.; Tsianos, E.V.; Ioannidis, J.P. Differential effects of NOD2 variants on Crohn's disease risk and phenotype in diverse populations: A meta-analysis. Am. J. Gastroenterol. 2004, 99, 2393-2404. [CrossRef] [PubMed]

20. Leong, R.W.; Armuzzi, A.; Ahmad, T.; Wong, M.L.; Tse, P.; Jewell, D.P.; Sung, J.J. NOD2/CARD15 gene polymorphisms and Crohn's disease in the Chinese population. Aliment. Pharmacol. Ther. 2003, 17, 1465-1470. [CrossRef] [PubMed]

21. Yamazaki, K.; Takazoe, M.; Tanaka, T.; Kazumori, T.; Nakamura, Y. Absence of mutation in the NOD2/CARD15 gene among 483 Japanese patients with Crohn's disease. J. Hum. Genet. 2002, 47, 469-472. [CrossRef]

22. Hugot, J.P.; Chamaillard, M.; Zouali, H.; Lesage, S.; Cezard, J.P.; Belaiche, J.; Almer, S.; Tysk, C.; O’Morain, C.A.; Gassull, M.; et al. Association of NOD2 leucine-rich repeat variants with susceptibility to Crohn's disease. Nature 2001, 411, 599-603. [CrossRef]

23. Rogler, G.; Hausmann, M. The long and winding road: From genetic risk factors to the understanding of disease-pathogenesis in Crohn's disease. Genes. Immun. 2019, 20, 607-608. [CrossRef]

24. Gajendran, M.; Loganathan, P.; Catinella, A.P.; Hashash, J.G. A comprehensive review and update on Crohn's disease. Dis. Mon. 2018, 64, 20-57. [CrossRef] [PubMed]

25. Plantinga, T.S.; Crisan, T.O.; Oosting, M.; van de Veerdonk, F.L.; de Jong, D.J.; Philpott, D.J.; van der Meer, J.W.; Girardin, S.E.; Joosten, L.A.; Netea, M.G. Crohn's disease-associated ATG16L1 polymorphism modulates pro-inflammatory cytokine responses selectively upon activation of NOD2. Gut 2011, 60, 1229-1235. [CrossRef] [PubMed]

26. Coccia, M.; Harrison, O.J.; Schiering, C.; Asquith, M.J.; Becher, B.; Powrie, F.; Maloy, K.J. IL-1beta mediates chronic intestinal inflammation by promoting the accumulation of IL-17A secreting innate lymphoid cells and CD4(+) Th17 cells. J. Exp. Med. 2012, 209, 1595-1609. [CrossRef]

27. Preza, G.C.; Yang, O.O.; Elliott, J.; Anton, P.A.; Ochoa, M.T. T lymphocyte density and distribution in human colorectal mucosa, and inefficiency of current cell isolation protocols. PLoS ONE 2015, 10, e0122723. [CrossRef]

28. Tindemans, I.; Joosse, M.E.; Samsom, J.N. Dissecting the heterogeneity in T-cell mediated inflammation in IBD. Cells 2020, 9 , 110. [CrossRef] [PubMed]

29. Nemeth, Z.H.; Bogdanovski, D.A.; Barratt-Stopper, P.; Paglinco, S.R.; Antonioli, L.; Rolandelli, R.H. Crohn's disease and ulcerative colitis show unique cytokine profiles. Cureus 2017, 9, e1177. [CrossRef]

30. Liu, H.; Dasgupta, S.; Fu, Y.; Bailey, B.; Roy, C.; Lightcap, E.; Faustin, B. Subsets of mononuclear phagocytes are enriched in the inflamed colons of patients with IBD. BMC Immunol. 2019, 20, 42. [CrossRef] 
31. Rovedatti, L.; Kudo, T.; Biancheri, P.; Sarra, M.; Knowles, C.H.; Rampton, D.S.; Corazza, G.R.; Monteleone, G.; di Sabatino, A.; Macdonald, T.T. Differential regulation of interleukin 17 and interferon gamma production in inflammatory bowel disease. Gut 2009, 58, 1629-1636. [CrossRef]

32. Breese, E.; Braegger, C.P.; Corrigan, C.J.; Walker-Smith, J.A.; MacDonald, T.T. Interleukin-2- and interferon-gamma-secreting T cells in normal and diseased human intestinal mucosa. Immunology 1993, 78, 127-131.

33. Fuss, I.J.; Neurath, M.; Boirivant, M.; Klein, J.S.; de la Motte, C.; Strong, S.A.; Fiocchi, C.; Strober, W. Disparate CD4+ lamina propria (LP) lymphokine secretion profiles in inflammatory bowel disease. Crohn's disease LP cells manifest increased secretion of IFN-gamma, whereas ulcerative colitis LP cells manifest increased secretion of IL-5. J. Immunol. 1996, 157, 1261-1270.

34. Verdier, J.; Begue, B.; Cerf-Bensussan, N.; Ruemmele, F.M. Compartmentalized expression of Th1 and Th17 cytokines in pediatric inflammatory bowel diseases. Inflamm. Bowel Dis. 2012, 18, 1260-1266. [CrossRef]

35. Park, J.H.; Jeong, D.Y.; Peyrin-Biroulet, L.; Eisenhut, M.; Shin, J.I. Insight into the role of TSLP in inflammatory bowel diseases. Autoimmun. Rev. 2017, 16, 55-63. [CrossRef] [PubMed]

36. Giuffrida, P.; Caprioli, F.; Facciotti, F.; di Sabatino, A. The role of interleukin-13 in chronic inflammatory intestinal disorders. Autoimmun. Rev. 2019, 18, 549-555. [CrossRef] [PubMed]

37. Maynard, C.L.; Weaver, C.T. Intestinal effector T cells in health and disease. Immunity 2009, 31, 389-400. [CrossRef] [PubMed]

38. Hansen, J.J. Immune responses to intestinal microbes in inflammatory bowel diseases. Curr. Allergy Asthma Rep. 2015, 15, 61. [CrossRef] [PubMed]

39. Maloy, K.J.; Powrie, F. Intestinal homeostasis and its breakdown in inflammatory bowel disease. Nature 2011, 474, 298-306. [CrossRef]

40. Duchmann, R.; Kaiser, I.; Hermann, E.; Mayet, W.; Ewe, K.; Meyer zum Buschenfelde, K.H. Tolerance exists towards resident intestinal flora but is broken in active inflammatory bowel disease (IBD). Clin. Exp. Immunol. 1995, 102, 448-455. [CrossRef]

41. Liu, S.; Zhao, W.; Lan, P.; Mou, X. The microbiome in inflammatory bowel diseases: From pathogenesis to therapy. Protein Cell 2021, 12, 331-345. [CrossRef]

42. Sartor, R.B. Mechanisms of disease: Pathogenesis of Crohn's disease and ulcerative colitis. Nat. Clin. Pract. Gastroenterol. Hepatol. 2006, 3, 390-407. [CrossRef]

43. Giuffrida, P.; Corazza, G.R.; di Sabatino, A. Old and new lymphocyte players in inflammatory bowel disease. Dig. Dis. Sci. 2018, 63, 277-288. [CrossRef] [PubMed]

44. Sepahi, A.; Liu, Q.; Friesen, L.; Kim, C.H. Dietary fiber metabolites regulate innate lymphoid cell responses. Mucosal Immunol. 2021, 14, 317-330. [CrossRef] [PubMed]

45. Luo, W.; Tian, L.; Tan, B.; Shen, Z.; Xiao, M.; Wu, S.; Meng, X.; Wu, X.; Wang, X. Update: Innate lymphoid cells in inflammatory bowel disease. Dig. Dis. Sci. 2021. [CrossRef]

46. Zhou, W.; Sonnenberg, G.F. Activation and suppression of group 3 innate lymphoid cells in the gut. Trends Immunol. 2020, 41, 721-733. [CrossRef]

47. Wu, Y.; Shen, J. Innate lymphoid cells in Crohn's disease. Front. Immunol. 2020, 11, 554880. [CrossRef] [PubMed]

48. Diefenbach, A.; Gnafakis, S.; Shomrat, O. Innate lymphoid cell-epithelial cell modules sustain intestinal homeostasis. Immunity 2020, 52, 452-463. [CrossRef] [PubMed]

49. Cupedo, T.; Crellin, N.K.; Papazian, N.; Rombouts, E.J.; Weijer, K.; Grogan, J.L.; Fibbe, W.E.; Cornelissen, J.J.; Spits, H. Human fetal lymphoid tissue-inducer cells are interleukin 17-producing precursors to $\mathrm{RORC}^{+} \mathrm{CD} 127^{+}$natural killer-like cells. Nat. Immunol. 2009, 10, 66-74. [CrossRef]

50. Cella, M.; Fuchs, A.; Vermi, W.; Facchetti, F.; Otero, K.; Lennerz, J.K.; Doherty, J.M.; Mills, J.C.; Colonna, M. A human natural killer cell subset provides an innate source of IL-22 for mucosal immunity. Nature 2009, 457, 722-725. [CrossRef]

51. Spits, H.; Artis, D.; Colonna, M.; Diefenbach, A.; di Santo, J.P.; Eberl, G.; Koyasu, S.; Locksley, R.M.; McKenzie, A.N.; Mebius, R.E.; et al. Innate lymphoid cells-A proposal for uniform nomenclature. Nat. Rev. Immunol. 2013, 13, 145-149. [CrossRef]

52. Ignacio, A.; Breda, C.N.S.; Camara, N.O.S. Innate lymphoid cells in tissue homeostasis and diseases. World J. Hepatol. 2017, 9, 979-989. [CrossRef] [PubMed]

53. Eberl, G.; Colonna, M.; di Santo, J.P.; McKenzie, A.N. Innate lymphoid cells. Innate lymphoid cells: A new paradigm in immunology. Science 2015, 348, aaa6566. [CrossRef] [PubMed]

54. Artis, D.; Spits, H. The biology of innate lymphoid cells. Nature 2015, 517, 293-301. [CrossRef]

55. Huang, Y.; Mao, K.; Germain, R.N. Thinking differently about ILCs-Not just tissue resident and not just the same as CD4(+) T-cell effectors. Immunol. Rev. 2018, 286, 160-171. [CrossRef] [PubMed]

56. Trabanelli, S.; Gomez-Cadena, A.; Salome, B.; Michaud, K.; Mavilio, D.; Landis, B.N.; Jandus, P.; Jandus, C. Human innate lymphoid cells (ILCs): Toward a uniform immune-phenotyping. Cytom. Part B Clin. Cytom. 2018, 94, 392-399. [CrossRef]

57. Panda, S.K.; Colonna, M. Innate lymphoid cells in mucosal immunity. Front. Immunol. 2019, 10, 861. [CrossRef]

58. Gasteiger, G.; Fan, X.; Dikiy, S.; Lee, S.Y.; Rudensky, A.Y. Tissue residency of innate lymphoid cells in lymphoid and nonlymphoid organs. Science 2015, 350, 981-985. [CrossRef]

59. Savage, A.K.; Liang, H.E.; Locksley, R.M. The development of steady-state activation hubs between adult LTi ILC3s and primed macrophages in small intestine. J. Immunol. 2017, 199, 1912-1922. [CrossRef]

60. Sanos, S.L.; Bui, V.L.; Mortha, A.; Oberle, K.; Heners, C.; Johner, C.; Diefenbach, A. RORgammat and commensal microflora are required for the differentiation of mucosal interleukin 22-producing NKp46+ cells. Nat. Immunol. 2009, 10, 83-91. [CrossRef] 
61. Zook, E.C.; Kee, B.L. Development of innate lymphoid cells. Nat. Immunol. 2016, 17, 775-782. [CrossRef] [PubMed]

62. Lim, A.I.; Verrier, T.; Vosshenrich, C.A.; di Santo, J.P. Developmental options and functional plasticity of innate lymphoid cells. Curr. Opin. Immunol. 2017, 44, 61-68. [CrossRef]

63. Mjosberg, J.; Bernink, J.; Peters, C.; Spits, H. Transcriptional control of innate lymphoid cells. Eur. J. Immunol. 2012, 42, 1916-1923. [CrossRef] [PubMed]

64. Poggi, A.; Benelli, R.; Vene, R.; Costa, D.; Ferrari, N.; Tosetti, F.; Zocchi, M.R. Human gut-associated natural killer cells in health and disease. Front. Immunol. 2019, 10, 961. [CrossRef] [PubMed]

65. Simoni, Y.; Newell, E.W. Dissecting human ILC heterogeneity: More than just three subsets. Immunology 2018, 153, 297-303. [CrossRef]

66. Valle-Noguera, A.; Gomez-Sanchez, M.J.; Girard-Madoux, M.J.H.; Cruz-Adalia, A. Optimized protocol for characterization of mouse gut innate lymphoid cells. Front. Immunol. 2020, 11, 563414. [CrossRef] [PubMed]

67. Zhang, J.; Marotel, M.; Fauteux-Daniel, S.; Mathieu, A.L.; Viel, S.; Marcais, A.; Walzer, T. T-bet and Eomes govern differentiation and function of mouse and human NK cells and ILC1. Eur. J. Immunol. 2018, 48, 738-750. [CrossRef]

68. Serafini, N.; Vosshenrich, C.A.; di Santo, J.P. Transcriptional regulation of innate lymphoid cell fate. Nat. Rev. Immunol. 2015, 15, 415-428. [CrossRef]

69. Vivier, E.; Artis, D.; Colonna, M.; Diefenbach, A.; di Santo, J.P.; Eberl, G.; Koyasu, S.; Locksley, R.M.; McKenzie, A.N.J.; Mebius, R.E.; et al. Innate lymphoid cells: 10 years on. Cell 2018, 174, 1054-1066. [CrossRef]

70. Kim, C.H.; Hashimoto-Hill, S.; Kim, M. Migration and tissue tropism of innate lymphoid cells. Trends. Immunol. 2016, 37, 68-79. [CrossRef]

71. Meininger, I.; Carrasco, A.; Rao, A.; Soini, T.; Kokkinou, E.; Mjosberg, J. Tissue-specific features of innate lymphoid cells. Trends Immunol. 2020, 41, 902-917. [CrossRef]

72. Jiao, Y.; Huntington, N.D.; Belz, G.T.; Seillet, C. Type 1 innate lymphoid cell biology: Lessons learnt from natural killer cells. Front. Immunol. 2016, 7, 426. [CrossRef]

73. Bonne-Annee, S.; Bush, M.C.; Nutman, T.B. Differential modulation of human innate lymphoid cell (ILC) subsets by IL-10 and TGF-beta. Sci. Rep. 2019, 9, 14305. [CrossRef]

74. Hildreth, A.D.; O'Sullivan, T.E. Tissue-resident innate and innate-like lymphocyte responses to viral infection. Viruses 2019, 11, 272. [CrossRef]

75. Adams, N.M.; Sun, J.C. Spatial and temporal coordination of antiviral responses by group 1 ILCs. Immunol. Rev. 2018, 286, 23-36. [CrossRef]

76. Apraiz, A.; Benedicto, A.; Marquez, J.; Aguera-Lorente, A.; Asumendi, A.; Olaso, E.; Arteta, B. Innate lymphoid cells in the malignant melanoma microenvironment. Cancers 2020, 12, 3177. [CrossRef]

77. Molgora, M.; Cortez, V.S.; Colonna, M. Killing the invaders: NK cell impact in tumors and anti-tumor therapy. Cancers 2021, 13, 595. [CrossRef] [PubMed]

78. Sivori, S.; Pende, D.; Quatrini, L.; Pietra, G.; della Chiesa, M.; Vacca, P.; Tumino, N.; Moretta, F.; Mingari, M.C.; Locatelli, F.; et al. NK cells and ILCs in tumor immunotherapy. Mol. Aspects Med. 2020, 100870. [CrossRef] [PubMed]

79. Zitti, B.; Bryceson, Y.T. Natural killer cells in inflammation and autoimmunity. Cytokine Growth Factor Rev. 2018, 42, 37-46. [CrossRef] [PubMed]

80. Marcais, A.; Viel, S.; Grau, M.; Henry, T.; Marvel, J.; Walzer, T. Regulation of mouse NK cell development and function by cytokines. Front. Immunol. 2013, 4, 450. [CrossRef] [PubMed]

81. Kucuksezer, U.C.; Aktas Cetin, E.; Esen, F.; Tahrali, I.; Akdeniz, N.; Gelmez, M.Y.; Deniz, G. The role of natural killer cells in autoimmune diseases. Front. Immunol. 2021, 12, 622306. [CrossRef] [PubMed]

82. Elemam, N.M.; Hannawi, S.; Maghazachi, A.A. Innate Lymphoid Cells (ILCs) as mediators of inflammation, release of cytokines and lytic molecules. Toxins 2017, 9, 398. [CrossRef] [PubMed]

83. Peters, C.P.; Mjosberg, J.M.; Bernink, J.H.; Spits, H. Innate lymphoid cells in inflammatory bowel diseases. Immunol. Lett. 2016, 172, 124-131. [CrossRef] [PubMed]

84. Bernink, J.H.; Peters, C.P.; Munneke, M.; te Velde, A.A.; Meijer, S.L.; Weijer, K.; Hreggvidsdottir, H.S.; Heinsbroek, S.E.; Legrand, N.; Buskens, C.J.; et al. Human type 1 innate lymphoid cells accumulate in inflamed mucosal tissues. Nat. Immunol. 2013, 14, 221-229. [CrossRef]

85. Klose, C.S.N.; Flach, M.; Mohle, L.; Rogell, L.; Hoyler, T.; Ebert, K.; Fabiunke, C.; Pfeifer, D.; Sexl, V.; Fonseca-Pereira, D.; et al. Differentiation of type 1 ILCs from a common progenitor to all helper-like innate lymphoid cell lineages. Cell 2014, 157, 340-356. [CrossRef] [PubMed]

86. McKenzie, A.N.J.; Spits, H.; Eberl, G. Innate lymphoid cells in inflammation and immunity. Immunity 2014, 41, 366-374. [CrossRef] [PubMed]

87. Reynders, A.; Yessaad, N.; Vu Manh, T.P.; Dalod, M.; Fenis, A.; Aubry, C.; Nikitas, G.; Escaliere, B.; Renauld, J.C.; Dussurget, O.; et al. Identity, regulation and in vivo function of gut NKp46+RORgammat+ and NKp46+RORgammat- lymphoid cells. EMBO J. 2011, 30, 2934-2947. [CrossRef] [PubMed]

88. Weizman, O.E.; Adams, N.M.; Schuster, I.S.; Krishna, C.; Pritykin, Y.; Lau, C.; Degli-Esposti, M.A.; Leslie, C.S.; Sun, J.C.; O'Sullivan, T.E. ILC1 confer early host protection at initial sites of viral infection. Cell 2017, 171, 795-808.e12. [CrossRef] [PubMed] 
89. Helfrich, S.; Mindt, B.C.; Fritz, J.H.; Duerr, C.U. Group 2 innate lymphoid cells in respiratory allergic inflammation. Front. Immunol. 2019, 10, 930. [CrossRef]

90. Herbert, D.R.; Douglas, B.; Zullo, K. Group 2 innate lymphoid cells (ILC2): Type 2 immunity and Helminth immunity. Int. J. Mol. Sci. 2019, 20, 2276. [CrossRef]

91. Rafei-Shamsabadi, D.A.; Klose, C.S.N.; Halim, T.Y.F.; Tanriver, Y.; Jakob, T. Context dependent role of type 2 innate lymphoid cells in allergic skin inflammation. Front. Immunol. 2019, 10, 2591. [CrossRef] [PubMed]

92. Hwang, Y.Y.; McKenzie, A.N. Innate lymphoid cells in immunity and disease. Adv. Exp. Med. Biol. 2013, 785, 9-26.

93. Placek, K.; Schultze, J.L.; Netea, M.G. Immune memory characteristics of innate lymphoid cells. Curr. Opin. Infect. Dis. 2019, 32, 196-203. [CrossRef] [PubMed]

94. Martinez-Gonzalez, I.; Matha, L.; Steer, C.A.; Ghaedi, M.; Poon, G.F.; Takei, F. Allergen-experienced group 2 innate lymphoid cells acquire memory-like properties and enhance allergic lung inflammation. Immunity 2016, 45, 198-208. [CrossRef] [PubMed]

95. Eljaszewicz, A.; Ruchti, F.; Radzikowska, U.; Globinska, A.; Boonpiyathad, T.; Gschwend, A.; Morita, H.; Helbling, A.; Arasi, S.; Kahlert, H.; et al. Trained immunity and tolerance in innate lymphoid cells, monocytes, and dendritic cells during allergen-specific immunotherapy. J. Allergy Clin. Immunol. 2021, 147, 1865-1877. [CrossRef] [PubMed]

96. Kim, B.S.; Wojno, E.D.; Artis, D. Innate lymphoid cells and allergic inflammation. Curr. Opin. Immunol. 2013, 25, 738-744. [CrossRef]

97. Jiang, M.; Tao, S.; Zhang, S.; Wang, J.; Zhang, F.; Li, F.; Ding, J. Type 2 innate lymphoid cells participate in IL-33-stimulated Th2-associated immune response in chronic obstructive pulmonary disease. Exp. Ther. Med. 2019, 18, 3109-3116. [CrossRef]

98. Moro, K.; Yamada, T.; Tanabe, M.; Takeuchi, T.; Ikawa, T.; Kawamoto, H.; Furusawa, J.; Ohtani, M.; Fujii, H.; Koyasu, S. Innate production of $\mathrm{T}(\mathrm{H}) 2$ cytokines by adipose tissue-associated c-Kit(+)Sca-1(+) lymphoid cells. Nature 2010, 463, 540-544. [CrossRef]

99. Neill, D.R.; Wong, S.H.; Bellosi, A.; Flynn, R.J.; Daly, M.; Langford, T.K.; Bucks, C.; Kane, C.M.; Fallon, P.G.; Pannell, R.; et al. Nuocytes represent a new innate effector leukocyte that mediates type-2 immunity. Nature 2010, 464, 1367-1370. [CrossRef]

100. Price, A.E.; Liang, H.E.; Sullivan, B.M.; Reinhardt, R.L.; Eisley, C.J.; Erle, D.J.; Locksley, R.M. Systemically dispersed innate IL-13-expressing cells in type 2 immunity. Proc. Natl. Acad. Sci. USA 2010, 107, 11489-11494. [CrossRef]

101. Klein Wolterink, R.G.; Serafini, N.; van Nimwegen, M.; Vosshenrich, C.A.; de Bruijn, M.J.; Fonseca Pereira, D.; Veiga Fernandes, H.; Hendriks, R.W.; di Santo, J.P. Essential, dose-dependent role for the transcription factor Gata3 in the development of IL-5+ and IL-13+ type 2 innate lymphoid cells. Proc. Natl. Acad. Sci. USA 2013, 110, 10240-10245. [CrossRef]

102. Hoyler, T.; Klose, C.S.; Souabni, A.; Turqueti-Neves, A.; Pfeifer, D.; Rawlins, E.L.; Voehringer, D.; Busslinger, M.; Diefenbach, A. The transcription factor GATA-3 controls cell fate and maintenance of type 2 innate lymphoid cells. Immunity 2012, 37, 634-648. [CrossRef]

103. Spooner, C.J.; Lesch, J.; Yan, D.; Khan, A.A.; Abbas, A.; Ramirez-Carrozzi, V.; Zhou, M.; Soriano, R.; Eastham-Anderson, J.; Diehl, L.; et al. Specification of type 2 innate lymphocytes by the transcriptional determinant Gfi1. Nat. Immunol. 2013, 14, 1229-1236. [CrossRef]

104. Yu, Y.; Wang, C.; Clare, S.; Wang, J.; Lee, S.C.; Brandt, C.; Burke, S.; Lu, L.; He, D.; Jenkins, N.A.; et al. The transcription factor $\mathrm{Bcl11b}$ is specifically expressed in group 2 innate lymphoid cells and is essential for their development. J. Exp. Med. 2015, 212, 865-874. [CrossRef] [PubMed]

105. Qiu, J.; Heller, J.J.; Guo, X.; Chen, Z.M.; Fish, K.; Fu, Y.X.; Zhou, L. The aryl hydrocarbon receptor regulates gut immunity through modulation of innate lymphoid cells. Immunity 2012, 36, 92-104. [CrossRef] [PubMed]

106. Britanova, L.; Diefenbach, A. Interplay of innate lymphoid cells and the microbiota. Immunol. Rev. 2017, 279, 36-51. [CrossRef] [PubMed]

107. Wang, Y.; Koroleva, E.P.; Kruglov, A.A.; Kuprash, D.V.; Nedospasov, S.A.; Fu, Y.X.; Tumanov, A.V. Lymphotoxin beta receptor signaling in intestinal epithelial cells orchestrates innate immune responses against mucosal bacterial infection. Immunity 2010, 32, 403-413. [CrossRef]

108. Tumanov, A.V.; Koroleva, E.P.; Guo, X.; Wang, Y.; Kruglov, A.; Nedospasov, S.; Fu, Y.X. Lymphotoxin controls the IL-22 protection pathway in gut innate lymphoid cells during mucosal pathogen challenge. Cell Host Microbe 2011, 10, 44-53. [CrossRef] [PubMed]

109. Sonnenberg, G.F.; Monticelli, L.A.; Alenghat, T.; Fung, T.C.; Hutnick, N.A.; Kunisawa, J.; Shibata, N.; Grunberg, S.; Sinha, R.; Zahm, A.M.; et al. Innate lymphoid cells promote anatomical containment of lymphoid-resident commensal bacteria. Science 2012, 336, 1321-1325. [CrossRef]

110. Luci, C.; Reynders, A.; Ivanov, I.I.; Cognet, C.; Chiche, L.; Chasson, L.; Hardwigsen, J.; Anguiano, E.; Banchereau, J.; Chaussabel, D.; et al. Influence of the transcription factor RORgammat on the development of NKp46+ cell populations in gut and skin. Nat. Immunol. 2009, 10, 75-82. [CrossRef]

111. Eberl, G.; Marmon, S.; Sunshine, M.J.; Rennert, P.D.; Choi, Y.; Littman, D.R. An essential function for the nuclear receptor RORgamma(t) in the generation of fetal lymphoid tissue inducer cells. Nat. Immunol. 2004, 5, 64-73. [CrossRef]

112. Mebius, R.E.; Rennert, P.; Weissman, I.L. Developing lymph nodes collect CD4+CD3- LTbeta+ cells that can differentiate to APC, NK cells, and follicular cells but not T or B cells. Immunity 1997, 7, 493-504. [CrossRef]

113. Klose, C.S.; Kiss, E.A.; Schwierzeck, V.; Ebert, K.; Hoyler, T.; d’Hargues, Y.; Goppert, N.; Croxford, A.L.; Waisman, A.; Tanriver, Y.; et al. A T-bet gradient controls the fate and function of CCR6-RORgammat+ innate lymphoid cells. Nature 2013, 494, 261-265. [CrossRef] 
114. Reboldi, A.; Arnon, T.I.; Rodda, L.B.; Atakilit, A.; Sheppard, D.; Cyster, J.G. IgA production requires B cell interaction with subepithelial dendritic cells in Peyer's patches. Science 2016, 352, aaf4822. [CrossRef] [PubMed]

115. Kruglov, A.A.; Grivennikov, S.I.; Kuprash, D.V.; Winsauer, C.; Prepens, S.; Seleznik, G.M.; Eberl, G.; Littman, D.R.; Heikenwalder, M.; Tumanov, A.V.; et al. Nonredundant function of soluble LTalpha3 produced by innate lymphoid cells in intestinal homeostasis. Science 2013, 342, 1243-1246. [CrossRef]

116. Takatori, H.; Kanno, Y.; Watford, W.T.; Tato, C.M.; Weiss, G.; Ivanov, I.I.; Littman, D.R.; O'Shea, J.J. Lymphoid tissue inducer-like cells are an innate source of IL-17 and IL-22. J. Exp. Med. 2009, 206, 35-41. [CrossRef] [PubMed]

117. Song, C.; Lee, J.S.; Gilfillan, S.; Robinette, M.L.; Newberry, R.D.; Stappenbeck, T.S.; Mack, M.; Cella, M.; Colonna, M. Unique and redundant functions of NKp46+ ILC3s in models of intestinal inflammation. J. Exp. Med. 2015, 212, 1869-1882. [CrossRef] [PubMed]

118. Zeng, B.; Shi, S.; Ashworth, G.; Dong, C.; Liu, J.; Xing, F. ILC3 function as a double-edged sword in inflammatory bowel diseases. Cell Death Dis. 2019, 10, 315. [CrossRef]

119. Powell, N.; Lo, J.W.; Biancheri, P.; Vossenkamper, A.; Pantazi, E.; Walker, A.W.; Stolarczyk, E.; Ammoscato, F.; Goldberg, R.; Scott, P.; et al. Interleukin 6 increases production of cytokines by colonic innate lymphoid cells in mice and patients with chronic intestinal inflammation. Gastroenterology 2015, 149, 456-467.e15. [CrossRef] [PubMed]

120. Pearson, C.; Thornton, E.E.; McKenzie, B.; Schaupp, A.L.; Huskens, N.; Griseri, T.; West, N.; Tung, S.; Seddon, B.P.; Uhlig, H.H.; et al. ILC3 GM-CSF production and mobilisation orchestrate acute intestinal inflammation. eLife 2016, 5, e10066. [CrossRef]

121. Kramer, B.; Goeser, F.; Lutz, P.; Glassner, A.; Boesecke, C.; Schwarze-Zander, C.; Kaczmarek, D.; Nischalke, H.D.; Branchi, V.; Manekeller, S.; et al. Compartment-specific distribution of human intestinal innate lymphoid cells is altered in HIV patients under effective therapy. PLoS Pathog. 2017, 13, e1006373. [CrossRef] [PubMed]

122. Fuchs, A.; Vermi, W.; Lee, J.S.; Lonardi, S.; Gilfillan, S.; Newberry, R.D.; Cella, M.; Colonna, M. Intraepithelial type 1 innate lymphoid cells are a unique subset of IL-12- and IL-15-responsive IFN-gamma-producing cells. Immunity 2013, 38, 769-781. [CrossRef]

123. Ochel, A.; Tiegs, G.; Neumann, K. Type 2 innate lymphoid cells in liver and gut: From current knowledge to future perspectives. Int. J. Mol. Sci. 2019, 20, 1896. [CrossRef] [PubMed]

124. Mackley, E.C.; Houston, S.; Marriott, C.L.; Halford, E.E.; Lucas, B.; Cerovic, V.; Filbey, K.J.; Maizels, R.M.; Hepworth, M.R.; Sonnenberg, G.F.; et al. CCR7-dependent trafficking of RORgamma(+) ILCs creates a unique microenvironment within mucosal draining lymph nodes. Nat. Commun. 2015, 6, 5862. [CrossRef] [PubMed]

125. Belkaid, Y.; Hand, T.W. Role of the microbiota in immunity and inflammation. Cell 2014, 157, 121-141. [CrossRef]

126. Constantinides, M.G. Interactions between the microbiota and innate and innate-like lymphocytes. J. Leukoc. Biol. 2018, 103, 409-419. [CrossRef] [PubMed]

127. Ganal-Vonarburg, S.C.; Duerr, C.U. The interaction of intestinal microbiota and innate lymphoid cells in health and disease throughout life. Immunology 2020, 159, 39-51. [CrossRef]

128. Blander, J.M.; Longman, R.S.; Iliev, I.D.; Sonnenberg, G.F.; Artis, D. Regulation of inflammation by microbiota interactions with the host. Nat. Immunol. 2017, 18, 851-860. [CrossRef]

129. Rooks, M.G.; Garrett, W.S. Gut microbiota, metabolites and host immunity. Nat. Rev. Immunol. 2016, 16, 341-352. [CrossRef]

130. Chun, E.; Lavoie, S.; Fonseca-Pereira, D.; Bae, S.; Michaud, M.; Hoveyda, H.R.; Fraser, G.L.; Gallini Comeau, C.A.; Glickman, J.N.; Fuller, M.H.; et al. Metabolite-sensing receptor Ffar2 regulates colonic group 3 innate lymphoid cells and gut immunity. Immunity 2019, 51, 871-884.e6. [CrossRef]

131. Sawa, S.; Lochner, M.; Satoh-Takayama, N.; Dulauroy, S.; Berard, M.; Kleinschek, M.; Cua, D.; di Santo, J.P.; Eberl, G. RORgammat+ innate lymphoid cells regulate intestinal homeostasis by integrating negative signals from the symbiotic microbiota. Nat. Immunol. 2011, 12, 320-326. [CrossRef] [PubMed]

132. Kim, S.H.; Cho, B.H.; Kiyono, H.; Jang, Y.S. Microbiota-derived butyrate suppresses group 3 innate lymphoid cells in terminal ileal Peyer's patches. Sci. Rep. 2017, 7, 3980. [CrossRef] [PubMed]

133. Thio, C.L.; Chi, P.Y.; Lai, A.C.; Chang, Y.J. Regulation of type 2 innate lymphoid cell-dependent airway hyperreactivity by butyrate. J. Allergy Clin. Immunol. 2018, 142, 1867-1883.e12. [CrossRef]

134. Toki, S.; Goleniewska, K.; Reiss, S.; Zhou, W.; Newcomb, D.C.; Bloodworth, M.H.; Stier, M.T.; Boyd, K.L.; Polosukhin, V.V.; Subramaniam, S.; et al. The histone deacetylase inhibitor trichostatin A suppresses murine innate allergic inflammation by blocking group 2 innate lymphoid cell (ILC2) activation. Thorax 2016, 71, 633-645. [CrossRef] [PubMed]

135. Barrow, A.D.; Martin, C.J.; Colonna, M. The natural cytotoxicity receptors in health and disease. Front. Immunol. 2019, 10, 909. [CrossRef] [PubMed]

136. Glatzer, T.; Killig, M.; Meisig, J.; Ommert, I.; Luetke-Eversloh, M.; Babic, M.; Paclik, D.; Bluthgen, N.; Seidl, R.; Seifarth, C.; et al. RORgammat(+) innate lymphoid cells acquire a proinflammatory program upon engagement of the activating receptor NKp44. Immunity 2013, 38, 1223-1235. [CrossRef]

137. Castleman, M.J.; Dillon, S.M.; Purba, C.M.; Cogswell, A.C.; Kibbie, J.J.; McCarter, M.D.; Santiago, M.L.; Barker, E.; Wilson, C.C. Commensal and pathogenic bacteria indirectly induce IL-22 but not IFNgamma production from human colonic ILC3s via multiple mechanisms. Front. Immunol. 2019, 10, 649. [CrossRef]

138. Crellin, N.K.; Trifari, S.; Kaplan, C.D.; Satoh-Takayama, N.; di Santo, J.P.; Spits, H. Regulation of cytokine secretion in human CD127(+) LTi-like innate lymphoid cells by Toll-like receptor 2. Immunity 2010, 33, 752-764. [CrossRef] 
139. Mortha, A.; Chudnovskiy, A.; Hashimoto, D.; Bogunovic, M.; Spencer, S.P.; Belkaid, Y.; Merad, M. Microbiota-dependent crosstalk between macrophages and ILC3 promotes intestinal homeostasis. Science 2014, 343, 1249288. [CrossRef]

140. Zhou, L.; Chu, C.; Teng, F.; Bessman, N.J.; Goc, J.; Santosa, E.K.; Putzel, G.G.; Kabata, H.; Kelsen, J.R.; Baldassano, R.N.; et al. Innate lymphoid cells support regulatory T cells in the intestine through interleukin-2. Nature 2019, 568, 405-409. [CrossRef]

141. Bauche, D.; Joyce-Shaikh, B.; Jain, R.; Grein, J.; Ku, K.S.; Blumenschein, W.M.; Ganal-Vonarburg, S.C.; Wilson, D.C.; McClanahan, T.K.; Malefyt, R.W.; et al. LAG3(+) regulatory T cells restrain interleukin-23-producing CX3CR1(+) gut-resident macrophages during group 3 innate lymphoid cell-driven colitis. Immunity 2018, 49, 342-352.e5. [CrossRef]

142. Bartizal, K.F.; Salkowski, C.; Pleasants, J.R.; Balish, E. The effect of microbial flora, diet, and age on the tumoricidal activity of natural killer cells. J. Leukoc. Biol. 1984, 36, 739-750. [CrossRef]

143. Abt, M.C.; Osborne, L.C.; Monticelli, L.A.; Doering, T.A.; Alenghat, T.; Sonnenberg, G.F.; Paley, M.A.; Antenus, M.; Williams, K.L.; Erikson, J.; et al. Commensal bacteria calibrate the activation threshold of innate antiviral immunity. Immunity 2012, 37, 158-170. [CrossRef] [PubMed]

144. Ganal, S.C.; Sanos, S.L.; Kallfass, C.; Oberle, K.; Johner, C.; Kirschning, C.; Lienenklaus, S.; Weiss, S.; Staeheli, P.; Aichele, P.; et al. Priming of natural killer cells by nonmucosal mononuclear phagocytes requires instructive signals from commensal microbiota. Immunity 2012, 37, 171-186. [CrossRef] [PubMed]

145. Kamimura, Y.; Lanier, L.L. Homeostatic control of memory cell progenitors in the natural killer cell lineage. Cell Rep. 2015, 10, 280-291. [CrossRef]

146. Bouskra, D.; Brezillon, C.; Berard, M.; Werts, C.; Varona, R.; Boneca, I.G.; Eberl, G. Lymphoid tissue genesis induced by commensals through NOD1 regulates intestinal homeostasis. Nature 2008, 456, 507-510. [CrossRef]

147. Gury-BenAri, M.; Thaiss, C.A.; Serafini, N.; Winter, D.R.; Giladi, A.; Lara-Astiaso, D.; Levy, M.; Salame, T.M.; Weiner, A.; David, E.; et al. The spectrum and regulatory landscape of intestinal innate lymphoid cells are shaped by the microbiome. Cell 2016, 166, 1231-1246.e13. [CrossRef] [PubMed]

148. Monticelli, L.A.; Sonnenberg, G.F.; Abt, M.C.; Alenghat, T.; Ziegler, C.G.; Doering, T.A.; Angelosanto, J.M.; Laidlaw, B.J.; Yang, C.Y.; Sathaliyawala, T.; et al. Innate lymphoid cells promote lung-tissue homeostasis after infection with influenza virus. Nat. Immunol. 2011, 12, 1045-1054. [CrossRef]

149. Kernbauer, E.; Ding, Y.; Cadwell, K. An enteric virus can replace the beneficial function of commensal bacteria. Nature 2014, 516, 94-98. [CrossRef] [PubMed]

150. Maggi, L.; Montaini, G.; Mazzoni, A.; Rossettini, B.; Capone, M.; Rossi, M.C.; Santarlasci, V.; Liotta, F.; Rossi, O.; Gallo, O.; et al. Human circulating group 2 innate lymphoid cells can express CD154 and promote IgE production. J. Allergy Clin. Immunol. 2017, 139, 964-976.e4. [CrossRef] [PubMed]

151. Von Moltke, J.; Ji, M.; Liang, H.E.; Locksley, R.M. Tuft-cell-derived IL-25 regulates an intestinal ILC2-epithelial response circuit. Nature 2016, 529, 221-225. [CrossRef] [PubMed]

152. Frisbee, A.L.; Saleh, M.M.; Young, M.K.; Leslie, J.L.; Simpson, M.E.; Abhyankar, M.M.; Cowardin, C.A.; Ma, J.Z.; Pramoonjago, P.; Turner, S.D.; et al. IL-33 drives group 2 innate lymphoid cell-mediated protection during Clostridium difficile infection. Nat. Commun. 2019, 10, 2712. [CrossRef]

153. Garrido-Mesa, N.; Schroeder, J.H.; Stolarczyk, E.; Gallagher, A.L.; Lo, J.W.; Bailey, C.; Campbell, L.; Sexl, V.; MacDonald, T.T.; Howard, J.K.; et al. T-bet controls intestinal mucosa immune responses via repression of type 2 innate lymphoid cell function. Mucosal Immunol. 2019, 12, 51-63. [CrossRef] [PubMed]

154. Zhu, P.; Zhu, X.; Wu, J.; He, L.; Lu, T.; Wang, Y.; Liu, B.; Ye, B.; Sun, L.; Fan, D.; et al. IL-13 secreted by ILC2s promotes the self-renewal of intestinal stem cells through circular RNA circPan3. Nat. Immunol. 2019, 20, 183-194. [CrossRef] [PubMed]

155. Xue, L.; Salimi, M.; Panse, I.; Mjosberg, J.M.; McKenzie, A.N.; Spits, H.; Klenerman, P.; Ogg, G. Prostaglandin D2 activates group 2 innate lymphoid cells through chemoattractant receptor-homologous molecule expressed on TH2 cells. J. Allergy Clin. Immunol. 2014, 133, 1184-1194. [CrossRef] [PubMed]

156. Monticelli, L.A.; Osborne, L.C.; Noti, M.; Tran, S.V.; Zaiss, D.M.; Artis, D. IL-33 promotes an innate immune pathway of intestinal tissue protection dependent on amphiregulin-EGFR interactions. Proc. Natl. Acad. Sci. USA 2015, 112, 10762-10767. [CrossRef] [PubMed]

157. Wallrapp, A.; Riesenfeld, S.J.; Burkett, P.R.; Kuchroo, V.K. Type 2 innate lymphoid cells in the induction and resolution of tissue inflammation. Immunol. Rev. 2018, 286, 53-73. [CrossRef]

158. Mullin, J.M.; Snock, K.V. Effect of tumor necrosis factor on epithelial tight junctions and transepithelial permeability. Cancer Res. 1990, 50, 2172-2176. [PubMed]

159. Clark, E.; Hoare, C.; Tanianis-Hughes, J.; Carlson, G.L.; Warhurst, G. Interferon gamma induces translocation of commensal Escherichia coli across gut epithelial cells via a lipid raft-mediated process. Gastroenterology 2005, 128, 1258-1267. [CrossRef] [PubMed]

160. Sonnenberg, G.F.; Fouser, L.A.; Artis, D. Border patrol: Regulation of immunity, inflammation and tissue homeostasis at barrier surfaces by IL-22. Nat. Immunol. 2011, 12, 383-390. [CrossRef] [PubMed]

161. Penny, H.A.; Hodge, S.H.; Hepworth, M.R. Orchestration of intestinal homeostasis and tolerance by group 3 innate lymphoid cells. Semin. Immunopathol. 2018, 40, 357-370. [CrossRef] 
162. Kinnebrew, M.A.; Buffie, C.G.; Diehl, G.E.; Zenewicz, L.A.; Leiner, I.; Hohl, T.M.; Flavell, R.A.; Littman, D.R.; Pamer, E.G. Interleukin 23 production by intestinal $\mathrm{CD} 103(+) \mathrm{CD} 11 \mathrm{~b}(+)$ dendritic cells in response to bacterial flagellin enhances mucosal innate immune defense. Immunity 2012, 36, 276-287. [CrossRef] [PubMed]

163. Wolk, K.; Kunz, S.; Witte, E.; Friedrich, M.; Asadullah, K.; Sabat, R. IL-22 increases the innate immunity of tissues. Immunity 2004, 21, 241-254. [CrossRef] [PubMed]

164. Zheng, Y.; Valdez, P.A.; Danilenko, D.M.; Hu, Y.; Sa, S.M.; Gong, Q.; Abbas, A.R.; Modrusan, Z.; Ghilardi, N.; de Sauvage, F.J.; et al. Interleukin-22 mediates early host defense against attaching and effacing bacterial pathogens. Nat. Med. 2008, 14, 282-289. [CrossRef]

165. Gronke, K.; Hernandez, P.P.; Zimmermann, J.; Klose, C.S.N.; Kofoed-Branzk, M.; Guendel, F.; Witkowski, M.; Tizian, C.; Amann, L.; Schumacher, F.; et al. Interleukin-22 protects intestinal stem cells against genotoxic stress. Nature 2019, 566, 249-253. [CrossRef] [PubMed]

166. Goto, Y.; Obata, T.; Kunisawa, J.; Sato, S.; Ivanov, I.I.; Lamichhane, A.; Takeyama, N.; Kamioka, M.; Sakamoto, M.; Matsuki, T.; et al. Innate lymphoid cells regulate intestinal epithelial cell glycosylation. Science 2014, 345, 1254009. [CrossRef] [PubMed]

167. Goto, Y.; Kiyono, H. Epithelial barrier: An interface for the cross-communication between gut flora and immune system. Immunol. Rev. 2012, 245, 147-163. [CrossRef] [PubMed]

168. Bry, L.; Falk, P.G.; Midtvedt, T.; Gordon, J.I. A model of host-microbial interactions in an open mammalian ecosystem. Science 1996, 273, 1380-1383. [CrossRef] [PubMed]

169. Hepworth, M.R.; Fung, T.C.; Masur, S.H.; Kelsen, J.R.; McConnell, F.M.; Dubrot, J.; Withers, D.R.; Hugues, S.; Farrar, M.A.; Reith, W.; et al. Immune tolerance. Group 3 innate lymphoid cells mediate intestinal selection of commensal bacteria-specific CD4(+) T cells. Science 2015, 348, 1031-1035. [CrossRef]

170. Hepworth, M.R.; Monticelli, L.A.; Fung, T.C.; Ziegler, C.G.; Grunberg, S.; Sinha, R.; Mantegazza, A.R.; Ma, H.L.; Crawford, A.; Angelosanto, J.M.; et al. Innate lymphoid cells regulate CD4+ T-cell responses to intestinal commensal bacteria. Nature 2013, 498, 113-117. [CrossRef] [PubMed]

171. DeGruttola, A.K.; Low, D.; Mizoguchi, A.; Mizoguchi, E. Current understanding of dysbiosis in disease in human and animal models. Inflamm. Bowel Dis. 2016, 22, 1137-1150. [CrossRef]

172. Jangid, A.; Fukuda, S.; Seki, M.; Horiuchi, T.; Suzuki, Y.; Taylor, T.D.; Ohno, H.; Prakash, T. Association of colitis with gutmicrobiota dysbiosis in clathrin adapter AP-1B knockout mice. PLoS ONE 2020, 15, e228358. [CrossRef] [PubMed]

173. Borowczyk, J.; Shutova, M.; Brembilla, N.C.; Boehncke, W.H. IL-25 (IL-17E) in epithelial immunology and pathophysiology. J. Allergy Clin. Immunol. 2021, 148, 40-52. [CrossRef] [PubMed]

174. Schulz-Kuhnt, A.; Wirtz, S.; Neurath, M.F.; Atreya, I. Regulation of human innate lymphoid cells in the context of mucosal inflammation. Front. Immunol. 2020, 11, 1062. [CrossRef] [PubMed]

175. Forkel, M.; van Tol, S.; Hoog, C.; Michaelsson, J.; Almer, S.; Mjosberg, J. Distinct Alterations in the composition of mucosal innate lymphoid cells in newly diagnosed and established Crohn's disease and ulcerative colitis. J. Crohns Colitis 2019, 13, 67-78. [CrossRef] [PubMed]

176. Geremia, A.; Arancibia-Carcamo, C.V.; Fleming, M.P.; Rust, N.; Singh, B.; Mortensen, N.J.; Travis, S.P.; Powrie, F. IL-23-responsive innate lymphoid cells are increased in inflammatory bowel disease. J. Exp. Med. 2011, 208, 1127-1133. [CrossRef]

177. Buonocore, S.; Ahern, P.P.; Uhlig, H.H.; Ivanov, I.I.; Littman, D.R.; Maloy, K.J.; Powrie, F. Innate lymphoid cells drive interleukin23-dependent innate intestinal pathology. Nature 2010, 464, 1371-1375. [CrossRef] [PubMed]

178. Powell, N.; Walker, A.W.; Stolarczyk, E.; Canavan, J.B.; Gokmen, M.R.; Marks, E.; Jackson, I.; Hashim, A.; Curtis, M.A.; Jenner, R.G.; et al. The transcription factor T-bet regulates intestinal inflammation mediated by interleukin-7 receptor+ innate lymphoid cells. Immunity 2012, 37, 674-684. [CrossRef] [PubMed]

179. Munoz, M.; Eidenschenk, C.; Ota, N.; Wong, K.; Lohmann, U.; Kuhl, A.A.; Wang, X.; Manzanillo, P.; Li, Y.; Rutz, S.; et al. Interleukin-22 induces interleukin-18 expression from epithelial cells during intestinal infection. Immunity 2015, 42, 321-331. [CrossRef]

180. Satoh-Takayama, N.; Vosshenrich, C.A.; Lesjean-Pottier, S.; Sawa, S.; Lochner, M.; Rattis, F.; Mention, J.J.; Thiam, K.; CerfBensussan, N.; Mandelboim, O.; et al. Microbial flora drives interleukin 22 production in intestinal NKp46+ cells that provide innate mucosal immune defense. Immunity 2008, 29, 958-970. [CrossRef] [PubMed]

181. Tsai, P.Y.; Zhang, B.; He, W.Q.; Zha, J.M.; Odenwald, M.A.; Singh, G.; Tamura, A.; Shen, L.; Sailer, A.; Yeruva, S.; et al. IL22 upregulates epithelial claudin-2 to drive diarrhea and enteric pathogen clearance. Cell Host Microbe 2017, 21, 671-681.e4. [CrossRef]

182. Li, J.; Shi, W.; Sun, H.; Ji, Y.; Chen, Y.; Guo, X.; Sheng, H.; Shu, J.; Zhou, L.; Cai, T.; et al. Activation of DR3 signaling causes loss of ILC3s and exacerbates intestinal inflammation. Nat. Commun. 2019, 10, 3371. [CrossRef]

183. Gerosa, F.; Baldani-Guerra, B.; Nisii, C.; Marchesini, V.; Carra, G.; Trinchieri, G. Reciprocal activating interaction between natural killer cells and dendritic cells. J. Exp. Med. 2002, 195, 327-333. [CrossRef]

184. Mocikat, R.; Braumuller, H.; Gumy, A.; Egeter, O.; Ziegler, H.; Reusch, U.; Bubeck, A.; Louis, J.; Mailhammer, R.; Riethmuller, G.; et al. Natural killer cells activated by MHC class I(low) targets prime dendritic cells to induce protective CD8 T cell responses. Immunity 2003, 19, 561-569. [CrossRef] 
185. Hosomi, S.; Grootjans, J.; Tschurtschenthaler, M.; Krupka, N.; Matute, J.D.; Flak, M.B.; Martinez-Naves, E.; Gomez del Moral, M.; Glickman, J.N.; Ohira, M.; et al. Intestinal epithelial cell endoplasmic reticulum stress promotes MULT1 up-regulation and NKG2D-mediated inflammation. J. Exp. Med. 2017, 214, 2985-2997. [CrossRef] [PubMed]

186. Ng, S.C.; Plamondon, S.; Al-Hassi, H.O.; English, N.; Gellatly, N.; Kamm, M.A.; Knight, S.C.; Stagg, A.J. A novel population of human CD56+ human leucocyte antigen D-related (HLA-DR+) colonic lamina propria cells is associated with inflammation in ulcerative colitis. Clin. Exp. Immunol. 2009, 158, 205-218. [CrossRef] [PubMed]

187. Lin, L.; Ma, C.; Wei, B.; Aziz, N.; Rajalingam, R.; Yusung, S.; Erlich, H.A.; Trachtenberg, E.A.; Targan, S.R.; McGovern, D.P.; et al. Human NK cells licensed by killer Ig receptor genes have an altered cytokine program that modifies CD4+ T cell function. J. Immunol. 2014, 193, 940-949. [CrossRef]

188. Takayama, T.; Kamada, N.; Chinen, H.; Okamoto, S.; Kitazume, M.T.; Chang, J.; Matuzaki, Y.; Suzuki, S.; Sugita, A.; Koganei, K.; et al. Imbalance of NKp44(+)NKp46(-) and NKp44(-)NKp46(+) natural killer cells in the intestinal mucosa of patients with Crohn's disease. Gastroenterology 2010, 139, 882-892.e3. [CrossRef] [PubMed]

189. Gwela, A.; Siddhanathi, P.; Chapman, R.W.; Travis, S.; Powrie, F.; Arancibia-Carcamo, C.V.; Geremia, A. Th1 and innate lymphoid cells accumulate in primary sclerosing cholangitis-associated inflammatory bowel disease. J. Crohns Colitis 2017, 11, 1124-1134. [CrossRef] [PubMed]

190. Kobori, A.; Yagi, Y.; Imaeda, H.; Ban, H.; Bamba, S.; Tsujikawa, T.; Saito, Y.; Fujiyama, Y.; Andoh, A. Interleukin-33 expression is specifically enhanced in inflamed mucosa of ulcerative colitis. J. Gastroenterol. 2010, 45, 999-1007. [CrossRef] [PubMed]

191. Schiering, C.; Krausgruber, T.; Chomka, A.; Frohlich, A.; Adelmann, K.; Wohlfert, E.A.; Pott, J.; Griseri, T.; Bollrath, J.; Hegazy, A.N.; et al. The alarmin IL-33 promotes regulatory T-cell function in the intestine. Nature 2014, 513, 564-568. [CrossRef]

192. Camelo, A.; Barlow, J.L.; Drynan, L.F.; Neill, D.R.; Ballantyne, S.J.; Wong, S.H.; Pannell, R.; Gao, W.; Wrigley, K.; Sprenkle, J.; et al. Blocking IL-25 signalling protects against gut inflammation in a type-2 model of colitis by suppressing nuocyte and NKT derived IL-13. J. Gastroenterol. 2012, 47, 1198-1211. [CrossRef]

193. Jostins, L.; Ripke, S.; Weersma, R.K.; Duerr, R.H.; McGovern, D.P.; Hui, K.Y.; Lee, J.C.; Schumm, L.P.; Sharma, Y.; Anderson, C.A.; et al. Host-microbe interactions have shaped the genetic architecture of inflammatory bowel disease. Nature 2012, 491, 119-124. [CrossRef]

194. Mazzurana, L.; Bonfiglio, F.; Forkel, M.; d'Amato, M.; Halfvarson, J.; Mjosberg, J. Crohn's disease is associated with activation of circulating innate lymphoid cells. Inflamm. Bowel Dis. 2021, 27, 1128-1138. [CrossRef]

195. De Salvo, C.; Buela, K.A.; Creyns, B.; Corridoni, D.; Rana, N.; Wargo, H.L.; Cominelli, C.L.; Delaney, P.G.; Rodriguez-Palacios, A.; Cominelli, F.; et al. NOD2 drives early IL-33-dependent expansion of group 2 innate lymphoid cells during Crohn's disease-like ileitis. J. Clin. Investig. 2021, 131. [CrossRef]

196. Pizarro, T.T.; Pastorelli, L.; Bamias, G.; Garg, R.R.; Reuter, B.K.; Mercado, J.R.; Chieppa, M.; Arseneau, K.O.; Ley, K.; Cominelli, F. SAMP1/YitFc mouse strain: A spontaneous model of Crohn's disease-like ileitis. Inflamm. Bowel Dis. 2011, 17, $2566-2584$. [CrossRef]

197. Knipfer, L.; Schulz-Kuhnt, A.; Kindermann, M.; Greif, V.; Symowski, C.; Voehringer, D.; Neurath, M.F.; Atreya, I.; Wirtz, S. A CCL1/CCR8-dependent feed-forward mechanism drives ILC2 functions in type 2-mediated inflammation. J. Exp. Med. 2019, 216, 2763-2777. [CrossRef] [PubMed]

198. Puttur, F.; Denney, L.; Gregory, L.G.; Vuononvirta, J.; Oliver, R.; Entwistle, L.J.; Walker, S.A.; Headley, M.B.; McGhee, E.J.; Pease, J.E.; et al. Pulmonary environmental cues drive group 2 innate lymphoid cell dynamics in mice and humans. Sci. Immunol. 2019, 4, eaav7638. [CrossRef] [PubMed]

199. Caballer, M.A.V.; Gonzalez-Granado, J.M.; Zorita, V.; Abu Nabah, Y.N.; Silvestre-Roig, C.; del Monte-Monge, A.; Molina-Sanchez, P.; Ait-Oufella, H.; Andres-Manzano, M.J.; Sanz, M.J.; et al. Disruption of the CCL1-CCR8 axis inhibits vascular Treg recruitment and function and promotes atherosclerosis in mice. J. Mol. Cell. Cardiol. 2019, 132, 154-163. [CrossRef] [PubMed]

200. Fernández, B.H.; Gomez-Bris, R.; Somovilla-Crespo, B.; Gonzalez-Granado, J.M. Immunobiology of atherosclerosis: A complex net of interactions. Int. J. Mol. Sci. 2019, 20, 5293. [CrossRef]

201. Panina-Bordignon, P.; Papi, A.; Mariani, M.; di Lucia, P.; Casoni, G.; Bellettato, C.; Buonsanti, C.; Miotto, D.; Mapp, C.; Villa, A.; et al. The C-C chemokine receptors CCR4 and CCR8 identify airway T cells of allergen-challenged atopic asthmatics. J. Clin. Investig. 2001, 107, 1357-1364. [CrossRef]

202. Mikhak, Z.; Fukui, M.; Farsidjani, A.; Medoff, B.D.; Tager, A.M.; Luster, A.D. Contribution of CCR4 and CCR8 to antigen-specific $\mathrm{T}(\mathrm{H}) 2$ cell trafficking in allergic pulmonary inflammation. J. Allergy Clin. Immunol. 2009, 123, 67-73.e3. [CrossRef] [PubMed]

203. Barsheshet, Y.; Wildbaum, G.; Levy, E.; Vitenshtein, A.; Akinseye, C.; Griggs, J.; Lira, S.A.; Karin, N. CCR8(+)FOXp3(+) Treg cells as master drivers of immune regulation. Proc. Natl. Acad. Sci. USA 2017, 114, 6086-6091. [CrossRef] [PubMed]

204. Kang, L.; Schmalzl, A.; Leupold, T.; Gonzalez-Acera, M.; Atreya, R.; Neurath, M.F.; Becker, C.; Wirtz, S. CCR8 Signaling via CCL1 regulates responses of intestinal IFN-gamma producing innate lymphoid celis and protects from experimental colitis. Front. Immunol. 2020, 11, 609400. [CrossRef] [PubMed]

205. Lu, J.; Liu, D.; Tan, Y.; Deng, F.; Li, R. M1 Macrophage exosomes MiR-21a-5p aggravates inflammatory bowel disease through decreasing E-cadherin and subsequent ILC2 activation. J. Cell. Mol. Med. 2021, 25, 3041-3050. [CrossRef] [PubMed]

206. Schnoor, M. E-cadherin is important for the maintenance of intestinal epithelial homeostasis under basal and inflammatory conditions. Dig. Dis. Sci. 2015, 60, 816-818. [CrossRef] [PubMed] 
207. Xiong, X.; Cheng, Z.; Wu, F.; Hu, M.; Liu, Z.; Dong, R.; Chen, G. Berberine in the treatment of ulcerative colitis: A possible pathway through Tuft cells. Biomed. Pharmacother. 2021, 134, 111129. [CrossRef]

208. Bernink, J.H.; Krabbendam, L.; Germar, K.; de Jong, E.; Gronke, K.; Kofoed-Nielsen, M.; Munneke, J.M.; Hazenberg, M.D.; Villaudy, J.; Buskens, C.J.; et al. Interleukin-12 and -23 control plasticity of CD127(+) group 1 and group 3 innate lymphoid cells in the intestinal lamina propria. Immunity 2015, 43, 146-160. [CrossRef] [PubMed]

209. Vonarbourg, C.; Mortha, A.; Bui, V.L.; Hernandez, P.P.; Kiss, E.A.; Hoyler, T.; Flach, M.; Bengsch, B.; Thimme, R.; Holscher, C.; et al. Regulated expression of nuclear receptor RORgammat confers distinct functional fates to NK cell receptor-expressing RORgammat(+) innate lymphocytes. Immunity 2010, 33, 736-751. [CrossRef]

210. Tang, Y.; Tan, S.A.; Iqbal, A.; Li, J.; Glover, S.C. STAT3 genotypic variant rs744166 and increased tyrosine phosphorylation of STAT3 in IL-23 responsive innate lymphoid cells during pathogenesis of Crohn's disease. J. Immunol. Res. 2019, $2019,9406146$. [CrossRef]

211. Guo, X.; Qiu, J.; Tu, T.; Yang, X.; Deng, L.; Anders, R.A.; Zhou, L.; Fu, Y.X. Induction of innate lymphoid cell-derived interleukin-22 by the transcription factor STAT3 mediates protection against intestinal infection. Immunity 2014, 40, 25-39. [CrossRef]

212. Rankin, L.C.; Girard-Madoux, M.J.; Seillet, C.; Mielke, L.A.; Kerdiles, Y.; Fenis, A.; Wieduwild, E.; Putoczki, T.; Mondot, S.; Lantz, O.; et al. Complementarity and redundancy of IL-22-producing innate lymphoid cells. Nat. Immunol. 2016, 17, 179-186. [CrossRef]

213. Teunissen, M.B.M.; Munneke, J.M.; Bernink, J.H.; Spuls, P.I.; Res, P.C.M.; te Velde, A.; Cheuk, S.; Brouwer, M.W.D.; Menting, S.P.; Eidsmo, L.; et al. Composition of innate lymphoid cell subsets in the human skin: Enrichment of NCR(+) ILC3 in lesional skin and blood of psoriasis patients. J. Investig. Dermatol. 2014, 134, 2351-2360. [CrossRef]

214. Chea, S.; Perchet, T.; Petit, M.; Verrier, T.; Guy-Grand, D.; Banchi, E.G.; Vosshenrich, C.A.; di Santo, J.P.; Cumano, A.; Golub, R. Notch signaling in group 3 innate lymphoid cells modulates their plasticity. Sci. Signal. 2016, 9, ra45. [CrossRef]

215. Viant, C.; Rankin, L.C.; Girard-Madoux, M.J.; Seillet, C.; Shi, W.; Smyth, M.J.; Bartholin, L.; Walzer, T.; Huntington, N.D.; Vivier, E.; et al. Transforming growth factor-beta and Notch ligands act as opposing environmental cues in regulating the plasticity of type 3 innate lymphoid cells. Sci. Signal. 2016, 9, ra46. [CrossRef] [PubMed]

216. Ebbo, M.; Crinier, A.; Vely, F.; Vivier, E. Innate lymphoid cells: Major players in inflammatory diseases. Nat. Rev. Immunol. 2017, 17, 665-678. [CrossRef] [PubMed]

217. Travis, S.P.; Schnell, D.; Krzeski, P.; Abreu, M.T.; Altman, D.G.; Colombel, J.F.; Feagan, B.G.; Hanauer, S.B.; Lichtenstein, G.R.; Marteau, P.R.; et al. Reliability and initial validation of the ulcerative colitis endoscopic index of severity. Gastroenterology 2013, 145, 987-995. [CrossRef]

218. Lim, A.I.; Menegatti, S.; Bustamante, J.; le Bourhis, L.; Allez, M.; Rogge, L.; Casanova, J.L.; Yssel, H.; di Santo, J.P. IL-12 drives functional plasticity of human group 2 innate lymphoid cells. J. Exp. Med. 2016, 213, 569-583. [CrossRef]

219. Li, S.; Bostick, J.W.; Ye, J.; Qiu, J.; Zhang, B.; Urban, J.F., Jr.; Avram, D.; Zhou, L. Aryl hydrocarbon receptor signaling cell intrinsically inhibits intestinal group 2 innate lymphoid cell function. Immunity 2018, 49, 915-928.e5. [CrossRef]

220. Bal, S.M.; Bernink, J.H.; Nagasawa, M.; Groot, J.; Shikhagaie, M.M.; Golebski, K.; van Drunen, C.M.; Lutter, R.; Jonkers, R.E.; Hombrink, P.; et al. IL-1beta, IL-4 and IL-12 control the fate of group 2 innate lymphoid cells in human airway inflammation in the lungs. Nat. Immunol. 2016, 17, 636-645. [CrossRef] [PubMed]

221. De Salvo, C.; Buela, K.A.; Pizarro, T.T. Cytokine-mediated regulation of innate lymphoid cell plasticity in gut mucosal immunity. Front. Immunol. 2020, 11, 585319. [CrossRef] [PubMed]

222. Gao, Y.; Souza-Fonseca-Guimaraes, F.; Bald, T.; Ng, S.S.; Young, A.; Ngiow, S.F.; Rautela, J.; Straube, J.; Waddell, N.; Blake, S.J.; et al. Tumor immunoevasion by the conversion of effector NK cells into type 1 innate lymphoid cells. Nat. Immunol. 2017, 18, 1004-1015. [CrossRef] [PubMed]

223. Cortez, V.S.; Ulland, T.K.; Cervantes-Barragan, L.; Bando, J.K.; Robinette, M.L.; Wang, Q.; White, A.J.; Gilfillan, S.; Cella, M.; Colonna, M. SMAD4 impedes the conversion of NK cells into ILC1-like cells by curtailing non-canonical TGF-beta signaling. Nat. Immunol. 2017, 18, 995-1003. [CrossRef] [PubMed] 